\title{
Temporal variation of nitrate and phosphate transport in headwater catchments: the hydrological controls and land use alteration
}

\author{
T.-Y. Lee ${ }^{1}$, J.-C. Huang ${ }^{1}$, S.-J. Kao ${ }^{2,3}$, and C.-P. Tung ${ }^{4}$ \\ ${ }^{1}$ Department of Geography, National Taiwan University, Taipei, Taiwan \\ ${ }^{2}$ Research Center of Environmental Changes, Academia Sinica, Taipei, Taiwan \\ ${ }^{3}$ State Key Laboratory of Marine Environmental Science, Xiamen University, Xiamen, China \\ ${ }^{4}$ Department of Bioenvironmental Systems Engineering, National Taiwan University, Taipei, Taiwan
}

Correspondence to: J.-C. Huang (riverhuang@ntu.edu.tw)

Received: 14 July 2012 - Published in Biogeosciences Discuss.: 25 September 2012

Revised: 30 January 2013 - Accepted: 27 March 2013 - Published: 18 April 2013

\begin{abstract}
Oceania rivers are hotspots of DIN (dissolved inorganic nitrogen) and DIP (dissolved inorganic phosphorus) transport due to humid/warm climate, typhoon-induced episodic rainfall and high tectonic activity that create an environment favorable for high/rapid runoff and soil erosion. In spite of its uniqueness, effects of hydrologic controls and land use on the transport behaviors of DIN and DIP are rarely documented. A $2 \mathrm{yr}$ monitoring study for DIN and DIP from three headwater catchments with different cultivation gradient (0 To $8.9 \%$ ) was implemented during a $\sim 3$ day interval with an additional monitoring campaign at a $3 \mathrm{~h}$ interval during typhoon periods. Results showed the DIN yields in the pristine, moderately cultivated $(2.7 \%)$, and intensively cultivated $(8.9 \%)$ watersheds were $8.3,26$, and $37 \mathrm{~kg} \mathrm{Nha}^{-1} \mathrm{yr}^{-1}$, respectively. For the DIP yields, they were $0.36,0.35$, and $0.56 \mathrm{~kg} \mathrm{Pha}^{-1} \mathrm{yr}^{-1}$, respectively. Higher year-round DIN concentrations and five times larger in DIN yields in intensively cultivated watersheds indicate DIN is more sensitive to land use changes. The high background DIN yield from the relatively pristine watershed was likely due to high atmospheric nitrogen deposition and large subterranean $\mathrm{N}$ pool. The correlations between runoff and concentration reveals that typhoon floods purge out more DIN from the subterranean reservoir, i.e., soil, by contrast, runoff washes off surface soil resulting in higher suspended sediment with higher DIP. Collectively, typhoon runoff contributes $20-70 \%$ and $47-80 \%$, respectively, to the annual DIN and DIP exports. The DIN yield to DIP yield ratio varied from 97 to 410, which is higher than the global mean of $\sim 18$. Such a high ratio indicates a P-limiting condition in
\end{abstract}

stream and the downstream aquatic environment. Based on our field observation, we constructed a conceptual model illustrating different remobilization mechanisms for DIN and DIP from headwaters in a mountainous river, which is analogous to typical Oceania rivers and the headwater of large rivers in similar climate zones. Our study advanced our understanding about the role of cyclones, which exert hydrological control, and land use on nutrient export in the Oceania region, benefiting watershed management under the context of climate change.

\section{Introduction}

The global biogeochemical cycles of nitrogen $(\mathrm{N})$ and phosphorus $(\mathrm{P})$ have been significantly altered due to the increasing demand of food and energy consumption caused by increasing population and human activities (Galloway and Cowling, 2002; Seitzinger et al., 2010). In the past five decades, the rate at which biologically available nitrogen enters the terrestrial biosphere has doubled. The increase in the rate stems from human disturbances, such as fertilizer production, fossil fuel combustion, cultivation, and livestock industry (Galloway et al., 2004). The phosphorus entering into the environment has also been doubled due to mining and the use of rock phosphate as fertilizer, detergent additives, animal feed supplements, and other technical uses (Bennett et al., 2001; USGS, 2008). The increasing discharge of dissolved inorganic nitrogen (DIN) and phosphorus (DIP) from rivers may subsequently induce eutrophication in freshwater 
and coastal marine ecosystems (Turner et al., 2003; Duan et al., 2007; Conley et al., 2009) resulting in seasonal hypoxia, harmful algal blooms, and losses in fishery production in aquatic ecosystems (Lu et al., 2011; Billen and Garnier, 2007; Diaz and Rosenberg, 2008; Howarth et al., 1996; Rabalais, 1996). Moreover, the imbalanced export of DIN and DIP from land/soil that cause a change in the riverine DIN : DIP ratio may alter phytoplankton community structures, consequently, deteriorating the ecosystem (Justic et al., 1995; Howarth et al., 1996; Rabalais et al., 1996; Elser et al., 2009).

Oceania is a region centered on the islands of the tropical Pacific Ocean. Oceania ranges from the coral atolls and volcanic islands of South Pacific to the entire insular region between Asia and the Americas, including Australasia and the Malay Archipelago. Oceania rivers account for $4.5 \%$ of the total land surface area on Earth and export up to $12 \%$ and $35 \%$ of the global water and sediment discharge, respectively (Milliman et al., 1999). High precipitation, steep slopes, small basin areas, and frequent flood events can induce high erosion rates on Oceania islands (Kao and Milliman, 2008). The mass flux from such small rivers might also have unique biogeochemical significance since many of these rivers discharge material onto narrow shelves and canyons, facilitating material bypass to the deep sea (Milliman, 1995; Nittrouer et al., 1995; Carey et al., 2002; Lyons et al., 2002; Kao et al., 2006; Leithold et al., 2006). Model studies have demonstrated that Oceania rivers are significant sources of global DIN and DIP export (Seitzinger et al., 2005, 2010) and projected that the riverine $\mathrm{N}$ flux in Oceania will increase to over $10 \%$ by 2030 (Bouwman et al., 2005). However, those models are mainly extrapolation from large rivers with limited data from Oceania rivers (Meybeck, 1982; Caraco and Cole, 1999; Smith et al., 2003). A comprehensive study for Oceania rivers is difficult due to the effect of frequent typhoon events, which plays the critical role in material transport, on field sampling. By comparison, Taiwan has relatively abundant resources for researchers working on these topics (Kao and Liu, 2000; Kao et al., 2005).

Taiwan is a subtropical mountainous island with the maximum elevation of $\sim 4000 \mathrm{~m}$ a.s.l. and $\sim 70 \%$ of its area above $100 \mathrm{~m}$ a.s.l. The island-wide annual rainfall is approximately $\sim 2400 \mathrm{~mm}$, which is over 3 times of the global average (Legates, 1995). Due to steep slopes and small watersheds, about $70 \%$ of the annual rainfall turns into runoff. During May to October, the season of growing and fertilizer application for agriculture, 3-5 typhoons strike Taiwan, increasing episodic runoff facilitating high erosion and nutrient export to the aquatic system. In headwater catchments, agriculture-associated land use is limited by government rules, yet nutrient export is extremely sensitive to the runoff and land use type coverage (Huang et al., 2012b).

In this paper, we investigated the DIN and DIP fluxes for headwater catchments for two years (2007-2008). The nitrate and phosphate concentrations were measured in three headwater catchments representing different cultivation extents. These catchments were monitored during a 3 day inter$\mathrm{val}$, and were supplemented by typhoon sampling at a $3 \mathrm{~h}$ interval. The study is useful to the watershed biogeochemistry field because our work captured these fluxes for (1) Oceania, a globally significant region whose river exports are known to be significant and increasing; (2) smaller catchments, which represent lotic environments, that are most vulnerable to land use activities while at the same time critical to our understanding of source inputs to larger river systems; and (3) typhoon events of varying strength enabling some assessment of how fluxes behave during these events, which are likely to continue to change with climate variation.

\section{Study site}

The Chichiawan Watershed located in Central Taiwan has a drainage area of $105 \mathrm{~km}^{2}$ and elevations ranging from 1131 to $3882 \mathrm{~m}$ above sea level. The mean daily air temperature is $13.5^{\circ} \mathrm{C}$ with an average of $8.9^{\circ} \mathrm{C}$ in January and $17.7^{\circ} \mathrm{C}$ in July (see more details in Fig. 2). The annual runoff is $\sim 3300 \mathrm{~mm}$, and $\sim 75 \%$ of the runoff occurs during the wet season (May to October), primarily during the typhoon periods. In the remaining months (November to April in the next year, dry season) the other $25 \%$ occurs.

This creek consists of three major tributaries; namely, the Gaoshan $\left(\operatorname{area}=21 \mathrm{~km}^{2}\right)$, Yikawan $\left(\operatorname{area}=53 \mathrm{~km}^{2}\right)$, and Yusheng creeks (area $=31 \mathrm{~km}^{2}$ ) (Fig. 1). The Gaoshan and Yikawan creeks are the only habitat for the formosan landlocked salmon (Oncorhynchus masou formosanus) (Tung et al., 2006; Lee et al., 2012). In this study, the high-frequency water sampling sites were installed. $G$ stands for pristine watershed, Gaoshan Creek ( $0 \%$ cultivated land). $\mathrm{K}$ is located downstream of the intersection of Gaoshan Creek and Yikawan, which represents a moderate cultivation level ( $2.7 \%$ cultivation). Y stands for Yusheng Creek, which represents an intensively cultivated watershed (Table 1). Although the Yusheng Creek watershed has only $8.9 \%$ agriculture land, which is not intensive at all when compared to the cultivated extent in the Continents, this watershed has a low water quality index and degradation in benthic algae biodiversity (Yu et al., 2005). Moreover, the mountainous watersheds are more sensitive to farming activity (Huang et al., 2012b) where even a small percentage of cultivation is influential, particularly for the high water quality demand of the upstream biome.

Three precipitation gauges maintained by the Taiwan Power Company are located in this area (Fig. 1). The most western gauge monitors air temperature as well. Two hydrologic gauges monitor water levels, one for Yusheng Creek and one for the entire Chichiawan (all three creeks). The consecutive water levels will be transferred into hourly water discharge via a rating curve of water discharge against water level, which is calibrated each year. The most 


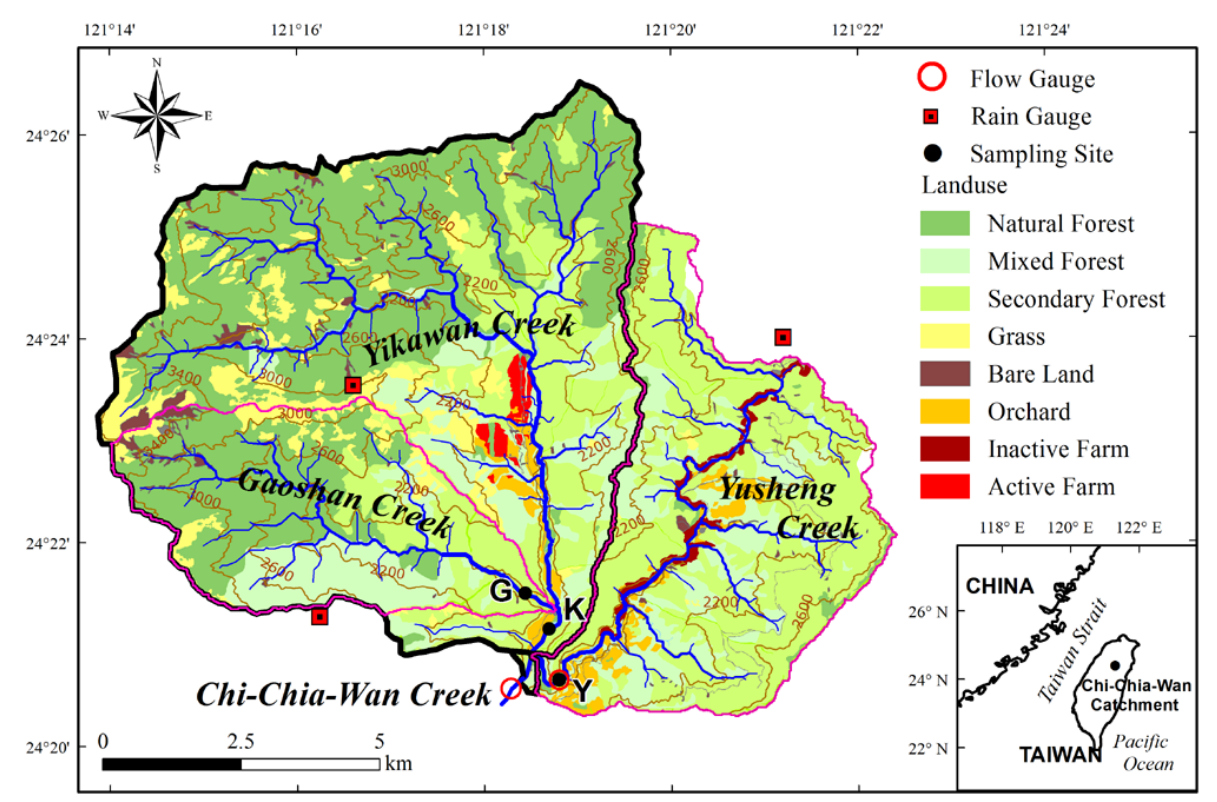

Fig. 1. The landscape of the study watershed, including sampling sites, rainfall gauges, discharge gauges and land use patterns. The study watershed was divided into three sub-catchments representing pristine (water samples taken at Sta. G), moderately cultivated (Sta. K), and intensively cultivated watersheds (Sta. Y).

Table 1. Basic landscape characteristics and land use patterns in the pristine, moderately cultivated, and intensively cultivated watersheds.

\begin{tabular}{|c|c|c|c|c|c|c|c|c|c|}
\hline & \multirow[b]{2}{*}{ Creek nam } & \multirow{2}{*}{\multicolumn{2}{|c|}{ Sta. ID }} & \multicolumn{6}{|c|}{ Landscape characteristics } \\
\hline & & & & \multicolumn{2}{|c|}{$\begin{array}{l}\text { Drainage area } \\
\qquad\left(\mathrm{km}^{2}\right)\end{array}$} & \multirow{2}{*}{$\begin{array}{c}\begin{array}{c}\text { Slope } \\
\text { (deg.) }\end{array} \\
74.4\end{array}$} & \multirow{2}{*}{$\begin{array}{c}\begin{array}{c}\text { Elevation } \\
(\mathrm{m})\end{array} \\
2577\end{array}$} & \multicolumn{2}{|c|}{$\begin{array}{l}\text { Max. flow length } \\
(\mathrm{km})\end{array}$} \\
\hline Pristine & Gaoshan & & G & & 05 & & & & .8 \\
\hline Moderately cultivated & Yikawan & & $\mathrm{K}$ & & 03 & 71.4 & 2581 & & 09 \\
\hline Intensively cultivated & Yusheng & & $\mathrm{Y}$ & & 92 & 56.8 & 2182 & & 48 \\
\hline Land uses & $\begin{array}{l}\text { Natural } \\
\text { forest }\end{array}$ & $\begin{array}{l}\text { Mixed } \\
\text { forest }\end{array}$ & $\mathrm{Sec}$ & $\begin{array}{l}\text { ondary } \\
\text { orest }\end{array}$ & Grass I & 3are land & Orchard & $\begin{array}{l}\text { Active } \\
\text { farm }\end{array}$ & $\begin{array}{c}\text { Inactive } \\
\text { farm }\end{array}$ \\
\hline unit & $\%$ & $\%$ & & $\%$ & $\%$ & $\%$ & $\%$ & $\%$ & $\%$ \\
\hline Pristine & 45.8 & 22.5 & & 19.7 & 9.7 & 2.2 & 0 & 0 & 0 \\
\hline Moderately cultivated & 47.4 & 15.9 & & 21.8 & 9.7 & 2 & 1.7 & 1 & 0 \\
\hline Intensively cultivated & 2.6 & 23.5 & & 62.9 & 0.8 & 1.9 & 5.2 & 0 & 3.7 \\
\hline
\end{tabular}

downstream gauge (Chichiawan) subtracts the discharge from the Yusheng Creek and is the discharge for the station (Sta.) K. The discharge for $\mathrm{G}$ is derived from an area proportion of Sta. K (Kao et al., 2004; Huang et al., 2012a). The average daily discharge for Chichiawan and Yusheng Creeks are 7.94 and $2.41 \mathrm{~m}^{3} \mathrm{~s}^{-1}$, respectively. During the wet season, the average daily discharges are 11.80 and $4.07 \mathrm{~m}^{3} \mathrm{~s}^{-1}$, respectively.

The study watersheds represent the typical landscape in mountainous regions (i.e., small proportion of agricultural activities located along the riparian zone) where some of the residents earn their living by growing vegetables and fruits (Huang et al., 2012b). The land use pattern and the land- scape characteristics for each catchment are shown in Fig. 1 and Table 1 . The natural forest, mixed forest, and secondary forest are the main land use types, and are patched by grass, bare land, orchard, active farm, and inactive farm. To rehabilitate the landlocked salmon, the cultivated farms along Yusheng Creek were expropriated by the government since 2005. The expropriated vegetable farms were categorized as inactive farms in this study. On the other hand, the currently producing farms, mainly cabbage, are designated as active farms (Huang et al., 2012b). The three adjacent creeks have similar environmental features, i.e., precipitation, atmospheric deposition, and geology, with varying cultivation gradients providing us a good experimental ground to explore 


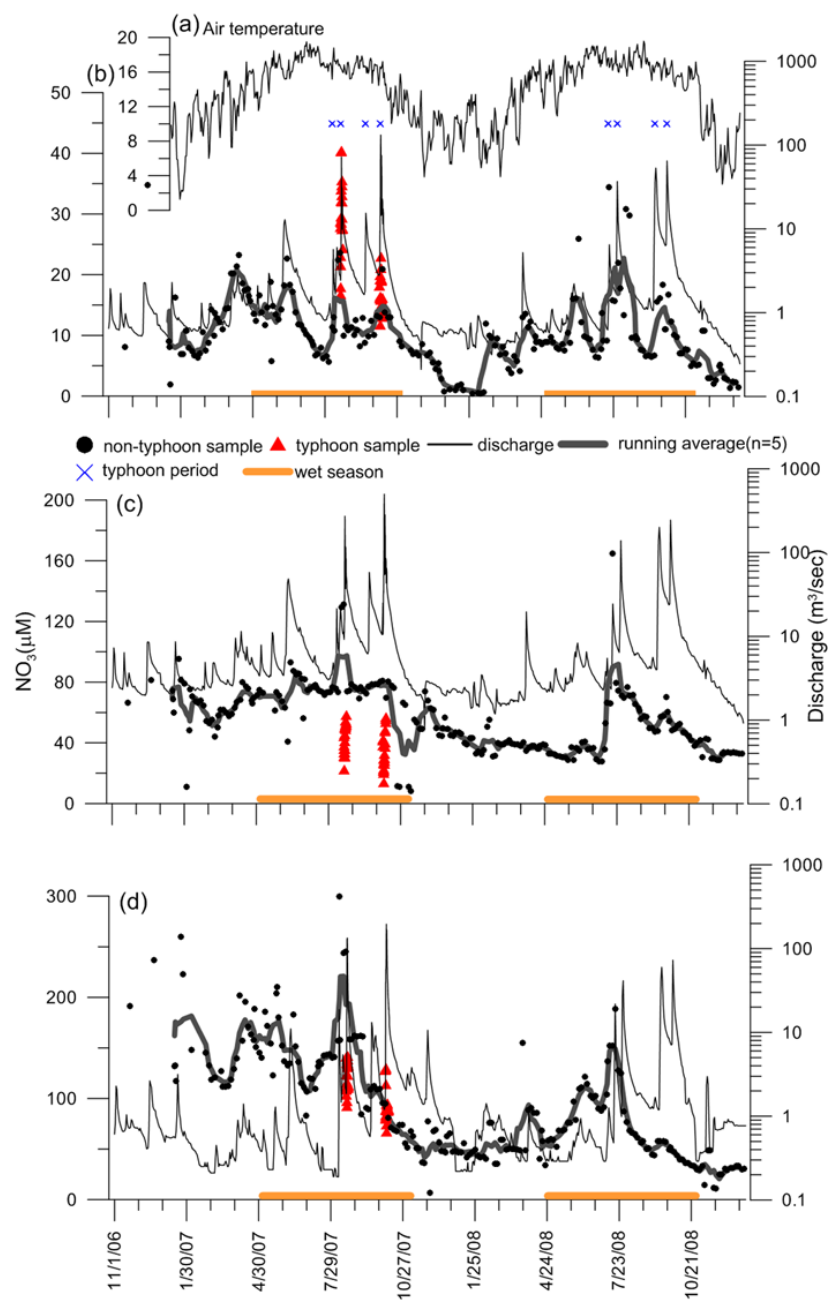

Fig. 2. The monitored (a) air temperature; discharge, and nitrate concentration in the (b) pristine, (c) moderately cultivated and (d) intensively cultivated watersheds. Water samples include typhoon (red triangle) and non-typhoon (black circle) samples. Eight typhoons were marked by cross symbol. The running average of 5 adjacent nitrate concentrations was illustrated by a thick grey line. Wet seasons were highlighted by a orange line on the $\mathrm{x}$-axis. Note that the data for the first typhoon we sampled was missing due to our negligence on sample storage.

the nutrient dynamics and differentiate anthropogenic alteration from natural background.

\section{Materials and methods}

\subsection{Water sampling and chemistry}

Water samples from the three stations were collected twice per week and analyzed during 2007 and 2008. Four typhoons in 2007 and four typhoons in 2008 brought the study site relatively large amounts of rainfall. Three among the four in 2007, Pabuk, Sepat, and Krosa during 6-8 August,
16-19 August, and 4-7 October, respectively, were sampled intensively at a $3 \mathrm{~h}$ interval for 62 to $87 \mathrm{~h}$. Depth integrated water samples were obtained using a vertically mounted $1 \mathrm{~L}$ bottle attached to a weighted metal frame that was gradually lowered from the bridge. The US Geological Survey DH-48 sampler was not used because of its difficulty in sinking in turbulent flows $>2.5 \mathrm{~m} \mathrm{~s}^{-1}$ (Milliman et al., 2007).

Water samples were immediately filtered through GF/F filters $(0.7 \mathrm{~mm})$. The filtrates were quick-frozen in liquid nitrogen for water chemistry analyses. Nitrate, nitrite and ammonium content were determined by ion chromatography (IC) using a Dionex ICS-1500 instrument with a detection limit of $0.2,0.2$, and $0.4 \mu \mathrm{M}$, respectively. For all samples, nitrite and ammonium concentrations were lower than the detection limit. Hence, nitrates are the dominant species of dissolved inorganic nitrogen (DIN). Phosphate, dissolved inorganic phosphorus (DIP), was determined with the standard Molybdenum blue method with the detection limit of $0.01 \mu \mathrm{M}$ (Parsons et al., 1984). During the typhoon period, total suspended matter (TSM) was determined gravimetrically using pre-combusted $0.7 \mathrm{~mm} \mathrm{GF/F} \mathrm{filters.} \mathrm{The} \mathrm{mean} \mathrm{of} \mathrm{the} \mathrm{blank,}$ calculated from ten replicates, was $0.05 \pm 0.01 \mathrm{mg} \mathrm{L}^{-1}$. This blank value was well below the weight of sediment on the filter (generally $>10 \mathrm{~g} \mathrm{~L}^{-1}$ ).

\subsection{Flux calculation}

The flux is the total amount of export of an element from a watershed within a given period. The elemental concentrations measured in the stream were transformed into flux by multiplying by the corresponding discharge to obtain the elemental mass load. We need the flux estimator to derive the flux within a given period when there are limited samples. These estimators are performed when continuous measurement (e.g., daily) of the constituent's concentration $(C)$ and discharge $(Q)$ is not possible. Two estimators, flowweighted method and rating curve methods, are implemented in this study for different circumstances. The flow-weighted method, which considers hydrological controls on element concentration, was applied to calculate the flux on nontyphoon days because typhoon discharge could change the $C-Q$ relation of the non-typhoon period (Lee et al., 2009). However, the close $C-Q$ relationship observed during the typhoon period makes the rating curve method suitable, particularly when the samples cover the higher-discharge spectrum (Kao and Liu, 2001; Kao et al., 2004, 2005; Kao and Milliman, 2008).

The formula for the flow-weighted method is shown below (Dolan et al., 1981; Coats et al., 2002).

$\operatorname{Load}_{\mathrm{NT}, m}=K_{1} \frac{\sum_{i=1}^{N_{m}} C_{i, m} Q_{i, m}}{\sum_{i=1}^{N_{m}} Q_{i, m}} \times Q_{t, m}, \quad m=1 \sim 12$ 
where $K_{1}$ is the conversion factor $\left(=10^{-3}\right.$, converting $\mathrm{g}$ to $\mathrm{kg}$ ) used to calculate $\operatorname{Load}_{\mathrm{NT}, \mathrm{m}}(\mathrm{kg})$ for a month, $m$. Subscript NT denotes non-typhoon days. $C_{i, m}\left(\mathrm{mg} \mathrm{L}^{-1}\right)$ is the nutrient concentration of $i$ th sample in a month. $Q_{i, m}$ $\left(\mathrm{m}^{3} \mathrm{~s}^{-1}\right)$ is the daily discharge on the day while the $i$ th sample is taken. $Q_{t, m}\left(\mathrm{~m}^{3}\right)$ is the total monthly discharge excluding typhoon days, and $N_{m}$ represents the total number of samples in a month.

The rating curve method presumes that a power function (i.e., $F=a Q^{b}$ ) exists between the observed elemental flux $(F)$ and discharge $(Q)$. The coefficients of power function, $a$ and $b$, in Eq. (2), can be derived from the observed elemental fluxes and the water discharge rates by the log-linear least-square method. In this study, $3 \mathrm{~h}$ interval samples are used to construct the power-function relation, which is further applied on the entire typhoon period to estimate the total typhoon load.

$\operatorname{Load}_{T}=K_{2} \sum_{j=1}^{t} F_{j}=K_{2} \sum_{j=1}^{t} a Q_{j}^{b}$,

where $K_{2}$ is also a conversion factor $(=3600 \mathrm{~s})$ used to calculate $\operatorname{Load}_{\mathrm{T}}(\mathrm{kg})$ for a specific period (in this case, typhoon hours). $T$ denotes typhoon period. $F_{j}\left(\mathrm{~g} \mathrm{~s}^{-1}\right)$ is the hourly elemental flux, which can be estimated by the hourly discharge rate $Q_{j}\left(\mathrm{~m}^{3} \mathrm{~s}^{-1}\right)$ on the $j$ th hour. $t(\mathrm{~h})$ is the total typhoon hour.

\section{Results}

The air temperature during observation varied from -4 to $\sim 25^{\circ} \mathrm{C}$ showing a significant annual cycle. In Fig. 2 we plotted daily average, thus the range is from 2 to $20^{\circ} \mathrm{C}$ (Fig. 2a). The water discharge is shown in Figs. 2 and 3. The discharge shows spikes ranging over three orders of magnitude, which is common and mostly attributed to typhoons, characteristic of small mountainous rivers (Milliman and Kao, 2005; Kao and Milliman, 2008).

\subsection{Temporal variation of nitrate and concentration- runoff relation}

In the pristine catchment (Sta. G) the nitrate concentration varied between $\sim 0.2$ to $\sim 40 \mu \mathrm{M}$ (Fig. $2 \mathrm{~b}$ ). The average nitrate concentration of typhoon samples, $23 \pm 8.4 \mu \mathrm{M}$, was higher than that in non-typhoon period, $10 \pm 5.7 \mu \mathrm{M}$ (Table 2). The nitrate concentration began to rise in the beginning of spring, i.e., onset of growing season in Taiwan, resembling the annual cycle of temperature. Generally, the higher concentrations were found in the wet season and the nitrate concentration seemed to correspond to the discharge patterns resulting in a positive concentration-runoff $(C-Q$, $Q$ in $\left.\left[\mathrm{mm} \mathrm{day}^{-1}\right]\right)$ relation during non-typhoon periods in Fig. 4a-1 (hollow circles). However, during a flood event period (i.e., typhoon period), dilution had occurred so that
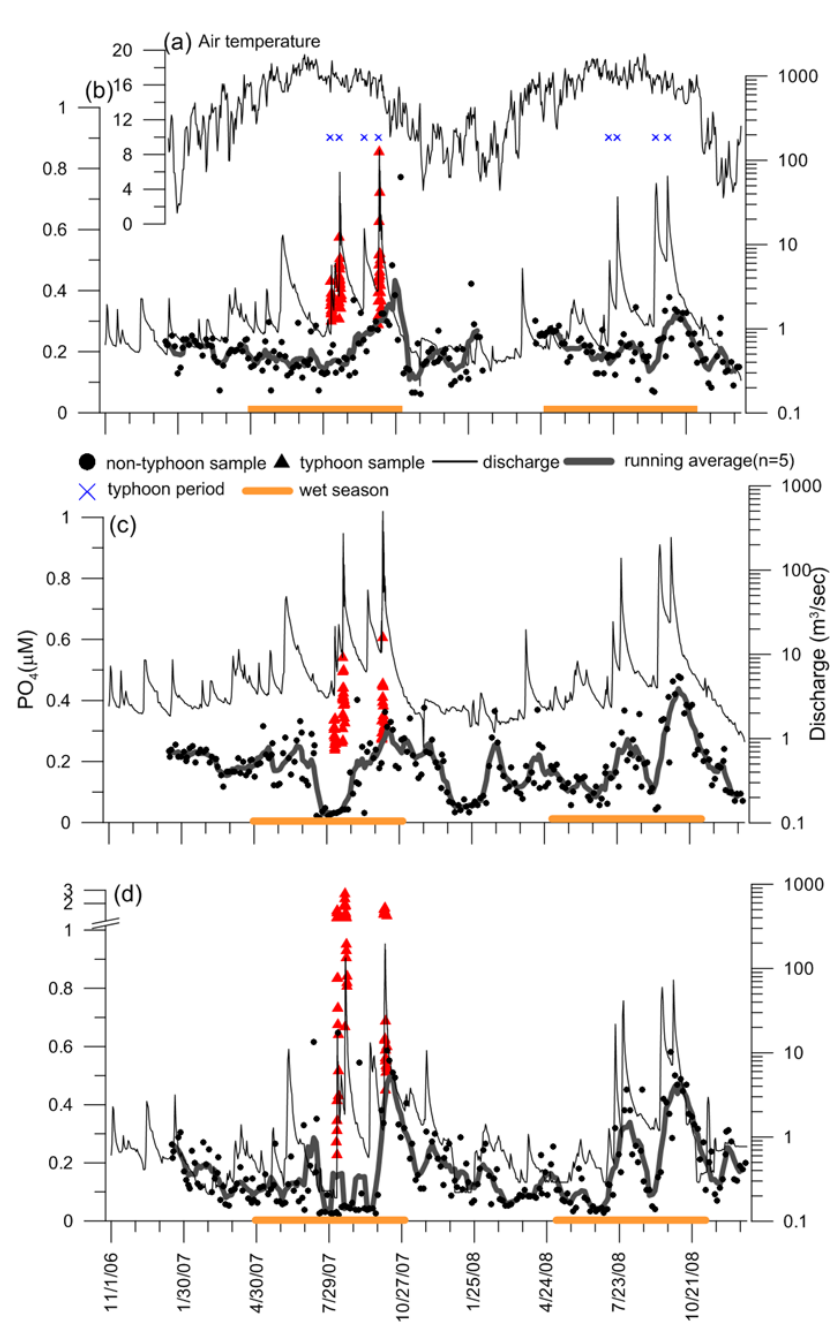

Fig. 3. The monitored (a) air temperature; discharge, and phosphate concentration in the (b) pristine, (c) moderately cultivated and (d) intensively cultivated watersheds. The same symbols were used as in Fig. 2. Note that, the $y$-axis for (d) plot is rescaled above $1 \mu \mathrm{M}$. The missing data in the beginning 2008 was due to our negligence on sample storage.

the nitrate concentrations decreased with the increasing discharge (solid circles in Fig. 4a-1). The $C-Q$ relation during typhoon events thus differed from that of non-typhoon periods.

Compared with the pristine watershed, nitrate concentrations at Sta. K (Fig. 2c) were higher ranging from $\sim 10$ to $\sim 200 \mu \mathrm{M}$ due to cultivation. Unlike in the pristine watershed (Fig. 2b), the overall mean nitrate concentration of the typhoon samples, $39 \pm 12 \mu \mathrm{M}$, was below the mean concentration measured during non-typhoon days, $55 \pm 21 \mu \mathrm{M}$ (Fig. 2c and Table 2). The annual cycle was not as apparent as in the pristine watershed. However, the rising nitrate concentration could still be found in the beginning of the growing season in 2007 but not in 2008. There were corresponding changes between nitrate concentration and discharge during 
Table 2. The means and coefficients of variation for nitrate, phosphate, and TSM concentration of water samples at three sites, including typhoon and non-typhoon samples. No TSM concentration was measured for non-typhoon samples. Non-typhoon samples were taken twice per week from 2007 to 2008 and typhoon samples were taken during three typhoon periods in 2007. See more detail in the text.

\begin{tabular}{lccc}
\hline Non-typhoon data & Pristine $(\mathrm{G})$ & Moderately cultivated $(\mathrm{K})$ & Intensively cultivated $(\mathrm{Y})$ \\
\hline Nitrate $(\mu \mathrm{M})$ & $10(0.56)^{*}$ & $55(0.38)$ & $92(0.58)$ \\
Phosphate $(\mu \mathrm{M})$ & $0.19(0.46)$ & $0.18(0.53)$ & $0.18(0.76)$ \\
\hline Typhoon data & & & \\
\hline Nitrate $(\mu \mathrm{M})$ & $23(0.36)$ & $39(0.30)$ & $108(0.19)$ \\
Phosphate $(\mu \mathrm{M})$ & $0.42(0.24)$ & $0.36(0.22)$ & $1.05(0.54)$ \\
TSM $\left(\mathrm{g} \mathrm{L}^{-1}\right)$ & $2.05(1.49)$ & $1.61(1.53)$ & $2.50(1.39)$ \\
\hline
\end{tabular}

* Values in parentheses represent coefficients of variation.

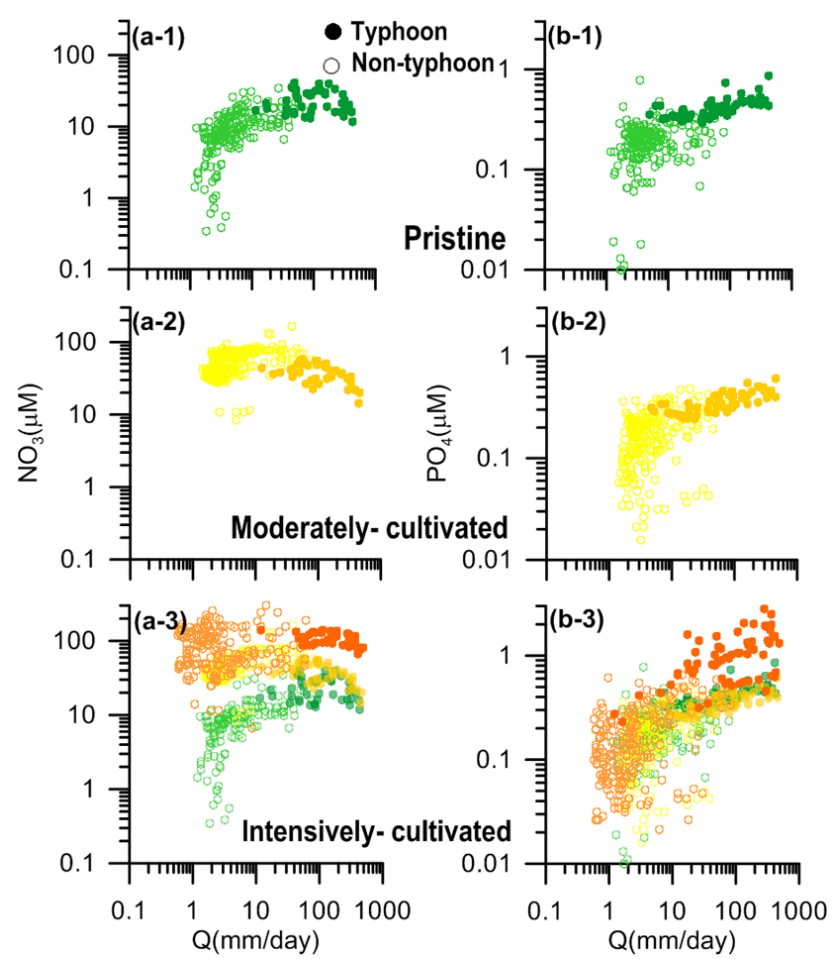

Fig. 4. The relation of observed (a) nitrate concentration and (b) phosphate concentration against runoff depth in the pristine $(-1$, green), moderately cultivated (-2, yellow) and intensively cultivated watersheds (-3, orange), respectively. Solid and hollow circles stand for typhoon and non-typhoon samples, separately. For the plots of intensively cultivated watershed, data in the other two watersheds were overlaid as references.

the non-typhoon period in 2007 , reflecting the positive $C-Q$ relation in Fig. 4a-2. However, in 2008 the nitrate concentration had only subtle fluctuation until the first typhoon raised the concentration, and the nitrate concentration kept decreasing afterwards (Fig. 2c). Note that in this year we did not monitor the water chemistry during flood peak. Nevertheless, nitrate concentrations were diluted by water discharge during the typhoon period in 2007 (Fig. 4a-2) as seen in the pristine watershed, and the dilution effect seemed to be more obvious.

At Sta. Y, the intensively cultivated watershed (Fig. 2d), nitrate concentration varied between $\sim 5$ to $300 \mu \mathrm{M}$. A significant higher baseline can be found in 2007 when comparing with that in 2008. The average nitrate concentration were $108 \pm 20 \mu \mathrm{M}$ for typhoon samples and $92 \pm 54 \mu \mathrm{M}$ for nontyphoon samples (Table 2). The observed concentrations at this station sometimes surpassed the criterion for drinking water quality, $\sim 160 \mu \mathrm{M}$. The nitrate concentration started to decrease since the midyear of 2007. Among the three watersheds, the decline of this nitrate falling from wet to dry season was the most significant. Again, dilution occurred during the typhoon period that can be seen in the $C-Q$ relation (Fig. 4a-3). For the three observed stations, the positive $C-Q$ relation during the non-typhoon period was alternating with the negative $C-Q$ relation during typhoon period.

\subsection{Temporal variation of phosphate and concentration-runoff relation}

The temporal variations of phosphate concentration for the three stations were shown in Fig. 3. At Sta. G, the pristine watershed, the phosphate concentration ranged from $\sim 0.01$ to $\sim 0.8 \mu \mathrm{M}$ with a mean of $0.19 \pm 0.09 \mu \mathrm{M}$ (Table 2). During the typhoon flood phosphate was much higher $(0.42 \pm 0.10 \mu \mathrm{M}$, red triangles in Fig. $3 \mathrm{~b})$ compared to nontyphoon periods. We could not see the tendency of rising phosphate concentration in the beginning of the growing season in either 2007 or 2008 as what we found for nitrate concentration (Fig. 2b). Opposite to nitrate, the phosphate concentrations were greater during the typhoon flood. The running average of the phosphate revealed a correspondence to the discharge pattern (Fig. 3b); however not as significantly as the nitrate did (Fig. 2b). A positive $C-Q$ relation was observed regardless of a non-typhoon or typhoon period (Fig. 4b-1).

At Sta. K, the phosphate concentration did not surpass $0.7 \mu \mathrm{M}$ (Fig. 3c). The mean of phosphate concentration for non-typhoon samples was $0.18 \pm 0.1 \mu \mathrm{M}$, comparable to the 


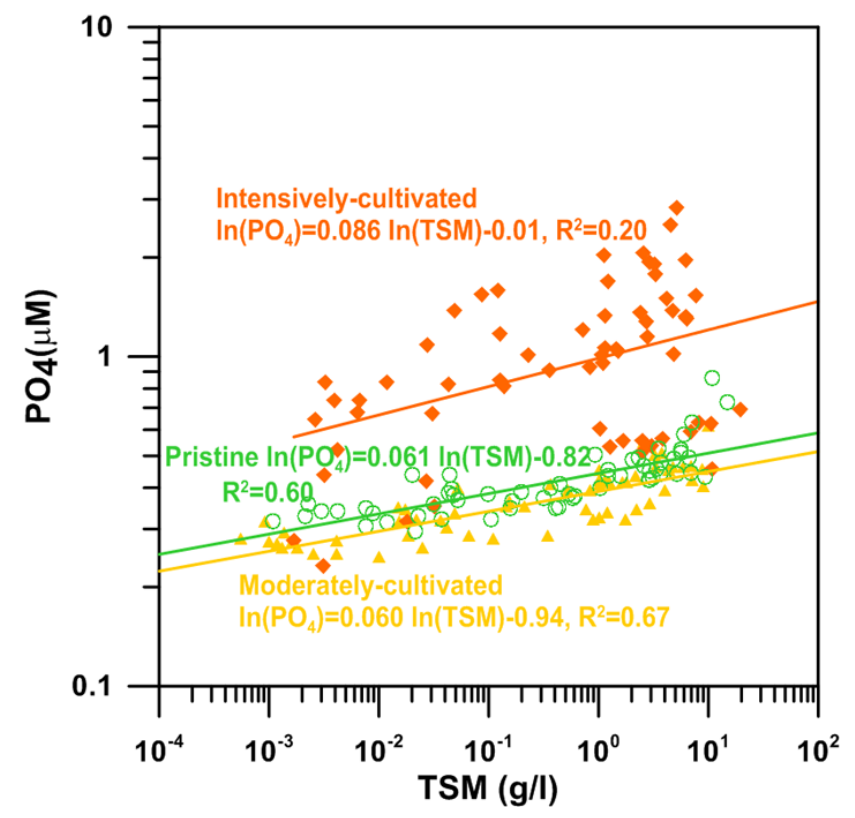

Fig. 5. The relations between observed phosphate concentrations against total suspended matter (TSM) for typhoon samples in the pristine (green), moderately cultivated (yellow) and intensively cultivated watersheds (orange), respectively.

pristine watershed (Table 2). The average of typhoon samples was $0.36 \pm 0.08 \mu \mathrm{M}$. A significant correspondence between discharge and phosphate concentration again reflected a positive $C-Q$ relation (Fig. $4 \mathrm{~b}-2$ ).

In the intensively cultivated watershed (Sta. Y), the observed phosphate concentrations during non-typhoon period were similar in range, $0.18 \pm 0.13 \mu \mathrm{M}$ (Table 2), as the other two (Fig. 4b-3). By contrast, phosphate concentration rose during the typhoon period with a maximum of $>2.8 \mu \mathrm{M}$, which is the highest concentration been observed in this study, reflecting the influence of fertilization. For all three stations, phosphate concentrations were enhanced as the increase of runoff depth (right panels of Fig. 4) regardless of agriculture and flow conditions.

During the typhoon period, those samples revealed positive yet significantly different correlations (see equations in Fig. 5) of phosphate concentration against TSM, The positive relations demonstrated that phosphate is highly particulateassociated. At a given TSM concentration the phosphate concentration is significantly higher but more scattering at Sta. Y where cultivated land proportion is the largest among the three. Interestingly, the pristine watershed may provide slightly higher phosphate concentration at a given TSM when compared with the moderately cultivated watershed.

\subsection{DIN to DIP ratio}

The monthly variations in ratio of DIN concentration $\left(\mathrm{DIN}_{\mathrm{C}}\right)$ to DIP concentration $\left(\mathrm{DIP}_{\mathrm{C}}\right)$ are illustrated in Fig. 6. The
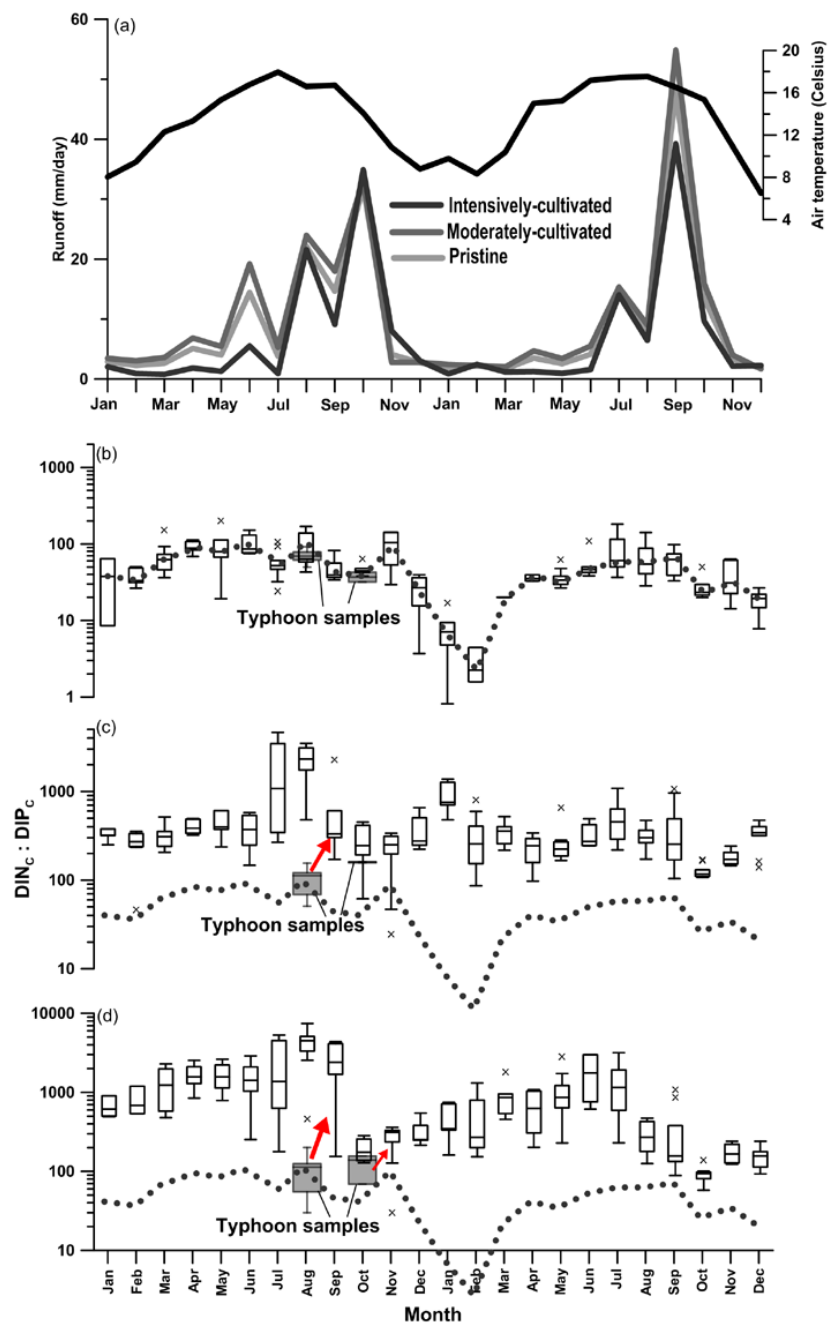

Fig. 6. (a) The monthly distribution of daily air temperature, runoff depth; and box-and-whisker plot of sampled DIN ${ }_{C}$ : DIP ${ }_{C}$ ratio in the (b) pristine, (c) moderately cultivated, and (d) intensively cultivated watersheds. Typhoon samples are highlighted separately in the grey box. Grey dashed line is the reference redrawn from the pristine watershed. Red arrows stands for the resilience of $\mathrm{DIN}_{\mathrm{C}}$ : DIP $_{C}$ ratio after a typhoon strike.

DIN $_{C}$ : DIP $_{C}$ fluctuated up to two orders of magnitude revealing the seasonality. At Sta. G, the DIN $_{C}$ to DIP $_{C}$ ratios varied from $\sim 2$ to $\sim 200$ (Fig. 6 b) generally following the temporal trend of air temperature (Fig. 6a) with lowest ratios in winter (dry period). The lowest $\mathrm{DIN}_{C}$ to $\mathrm{DIP}_{\mathrm{C}}$ ratios were mainly due to low DIN concentrations. The ratios during the typhoon periods were slightly lower compared with those in the same month but the overall trend still followed the annual temperature cycle.

At Sta. K, DIN ${ }_{C}:$ DIP $_{C}$ ranged from $\sim 50$ up to $\sim 5000$ (Fig. 6c) revealing remarkable difference of the pristine watershed reflecting the effect of agriculture. In early summer, a significant increase in DIN $_{C}$ : DIP $P_{C}$ was observed likely due to fertilizer application. After the peak, a gradually 
descending trend in monthly $\operatorname{DIN}_{C}$ : DIP $_{C}$ was seen as runoff increased. Note that during our typhoon observation, DIN $_{C}:$ DIP $_{C}$ values were the lowest throughout the year. These observed values dropped rapidly to a level similar to the pristine watershed in summer (dashed line in Fig. 6c), and an instant rebound to higher levels was also observed afterward in the following water samples. There were no evident correlations either between $\operatorname{DIN}_{C}$ : IIP $_{C}$ and air temperature or between DIN $_{C}:$ DIP $_{C}$ and discharge at Sta. K.

At Sta. Y, except for the typhoon observation, the DIN $_{C}:$ DIP $_{C}$ ranged from $\sim 200$ to $\sim 8000$, which is even higher than that at Sta. K. A gradual increase was detected from $\sim 500$ in January to $\sim 8000$ in August. Similar to Sta. K, a one-step jump in July and rapid drops of DIN $_{C}:$ DIP $_{C}$ in October can be seen (Fig. 6d). A significant feature is that the DIN ${ }_{C}$ to $\operatorname{DIP}_{C}$ ratio restarted to build up gradually from October in 2007 till July in 2008. The rapid drop to the level of $\sim 100$ during the typhoon period and rebound back after the typhoon indicates that such phenomena are common in agriculture watersheds.

The DIN $_{C}$ : DIP $_{C}$ versus DIP $\left(\right.$ Fig. 7a) and DIN $_{C}:$ DIP $_{C}$ versus runoff depth (Fig. 7b-d) were plotted to assess/illustrate the hydrological influence on $\mathrm{DIN}_{\mathrm{C}}$ : $\mathrm{DIP}_{\mathrm{C}}$ across cultivation gradients. In intensively cultivated conditions, $\mathrm{DIN}_{\mathrm{C}}$ : $\mathrm{DIP}_{\mathrm{C}}$ and $\mathrm{DIP}_{\mathrm{C}}$ correlated negatively and tightly in a much wider range in which $\operatorname{DIN}_{C}:$ DIP $_{C}$ is also roughly negatively correlated over a full range of runoff (Fig. 7b). At a given DIP $_{C}$, the intensively cultivated watershed had the highest DIN $_{C}$ : DIP $_{C}$ of the studied watersheds (Fig. 7a). The pristine watershed had a negative relation between $\operatorname{DIN}_{C}:$ DIP $_{C}$ and DIP $_{C}$. A dome shape in DIN $_{C}:$ DIP $_{C}$ of the pristine watershed forms over the full runoff range (Fig. 7d). Moderately cultivated watershed possessed, in the middle of aforementioned, two extreme cases. For comparison, we graphed the dry period samples together into fields (Fig. 7a) by watershed type. Interestingly, DIN $_{C}:$ DIP $_{C}$ tends to be higher at middle runoff condition regardless of cultivation degree (Fig. 7b, c and d) though less significant in the pristine watershed.

\subsection{DIN and DIP production}

The log-log relations of observed $\mathrm{N}$ and $\mathrm{P}$ fluxes against discharges are shown in Fig. 8. The strong, positive correlations illustrate that hydrology exerts strong control on both DIN and DIP exports - particularly, for the typhoon samples. The relations could be well depicted by a power function, i.e., rating curve method (Table 3 ). The coefficients of determination, i.e., $R^{2}$, were high $(>0.85)$, indicating the applicability of a rating curve method to estimate nutrient fluxes during a typhoon flood. Thus, the hourly discharge reported for the eight typhoon periods was substituted into the power functions to estimate nutrient fluxes during the typhoon period. For the non-typhoon period (hollow circles in Fig. 8) the relations were relatively scattered, and the degree of scatter was

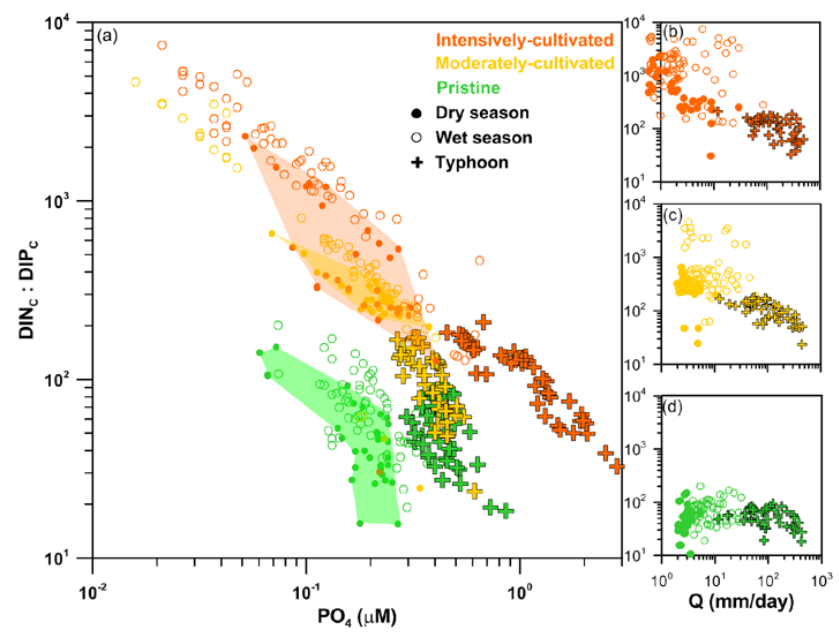

Fig. 7. (a) The distribution of observed $\mathrm{DIN}_{C}$ : $\mathrm{DIP}_{\mathrm{C}}$ ratio against phosphate concentrations under different hydrologic controls and cultivation levels. The relationship between the $\operatorname{DIN}_{C}$ : DIP $P_{C}$ ratio versus discharge for the (b) pristine (in green), (c) moderately cultivated (in yellow), and (d) intensively cultivated watersheds (in orange). The solid circle, hollow circle, and cross symbol represent the DIN $_{C}$ : DIP $_{C}$ sampled in dry season, wet season, and typhoon period, respectively. Except outliers, dry-season samples were grouped together in colored areas. Only data collected in 2007 were used.

much higher during low flow. Accordingly, during the nontyphoon period the monthly flow-weighted method was used to estimate monthly nutrient fluxes.

Since hydrology plays an important role in nutrient export, we would like to examine the fractional contribution from typhoon events to total nutrient export. In 2007, four typhoons collectively brought $30-50 \%$ of the annual total runoff of the three watersheds, resulting in $20-48 \%$ and $47-84 \%$ of annual DIN and DIP export, respectively. The four typhoons in 2008 contributed $48-55 \%$ of annual runoff carrying a slightly higher $(40-70 \%$ and $60-80 \%$ of annual DIN and DIP export) amount of nutrient transported off the watersheds.

The nutrient loads were converted into yield per area to illustrate the production rate of DIN and DIP (represented by $\operatorname{DIN}_{y}$ and $\mathrm{DIP}_{y}$, respectively) (Table 4). Cultivation is more influential on $\operatorname{DIN}_{y}$ than $\operatorname{DIP}_{y}$. DIN $y$ ranged from $7.9-8.6 \mathrm{~kg} \mathrm{Nha}^{-1} \mathrm{yr}^{-1}$ in the pristine watershed to $30-43 \mathrm{~kg} \mathrm{Nha}^{-1} \mathrm{yr}^{-1}$ in the intensively cultivated watershed. This result reflected the cultivation gradient captured

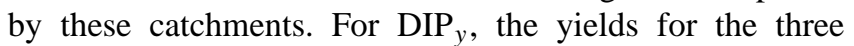
watersheds were $\sim 0.36, \sim 0.35$, and $\sim 0.56 \mathrm{~kg} \mathrm{Pha}^{-1} \mathrm{yr}^{-1}$, respectively. As mentioned above, hydrology regulates the relative yield of DIN to DIP; therefore, very different $\operatorname{DIN}_{y}$ : $\operatorname{DIP}_{y}$ can be seen during non-typhoon periods (103 to 1036) and typhoon periods (93 to 225), also the typhoon's higher fractional contribution resulted in annual means of 
Table 3. The power regression equation of typhoon samples taken for three study watersheds, and the runoff depth, calculated DIN load, and DIP load for the typhoon events in 2007 and 2008.

\begin{tabular}{|c|c|c|c|}
\hline $\begin{array}{l}\text { Rating curve, } \\
\text { Load }\left(\mathrm{kg} \mathrm{day}^{-1}\right)=a Q\left(\mathrm{~m}^{3} \mathrm{~s}^{-1}\right)^{\mathrm{b}}\end{array}$ & Pristine & Moderately cultivated & Intensively cultivated \\
\hline DIN load $\left(\mathrm{kg} \mathrm{N}\right.$ day $\left.^{-1}\right)$ & $29 Q^{0.97}(0.86)^{\mathrm{a}}$ & $117 Q^{0.79}(0.86)$ & $189 Q^{0.90}(0.95)$ \\
\hline DIP load (kg P day $\left.{ }^{-1}\right)$ & $0.85 Q^{1.11}(0.99)$ & $0.85 Q^{1.13}(0.99)$ & $1.18 Q^{1.23}(0.94)$ \\
\hline \multicolumn{4}{|c|}{$\begin{array}{l}2007 \text { typhoons } \\
\text { (Pabuk, 7-10 Aug; Sepat, 17-20 Aug; Wipha, 17-20 Sep; Krosa, 5-10 Oct) }\end{array}$} \\
\hline Runoff (mm) & $1253(33)^{b}$ & $1195(30)$ & $1395(50)$ \\
\hline DIN load (kg N) & $8043(44)$ & $45709(20)$ & $63985(48)$ \\
\hline DIP load (kg P) & $384(52)$ & 1114(47) & $1526(84)$ \\
\hline \multicolumn{4}{|c|}{$\begin{array}{l}2008 \text { typhoons } \\
\text { (Kalmaegi,17-20 Jul; Fung-Wong, 27 Jul-1 Aug; Sinlaku, 12-18 Sep; Jangmi,27 Sep-1 Oct) }\end{array}$} \\
\hline Runoff (mm) & $1655(48)$ & $1769(48)$ & $1384(55)$ \\
\hline DIN load (kg N) & $10645(64)$ & $67071(41)$ & $66940(70)$ \\
\hline DIP load (kg P) & $500(66)$ & $1642(60)$ & $1315(80)$ \\
\hline
\end{tabular}

a Values in parentheses represent coefficient of determination, i.e., $R^{2}$.

${ }^{b}$ Values in parentheses stand for the percentage of annual amount.
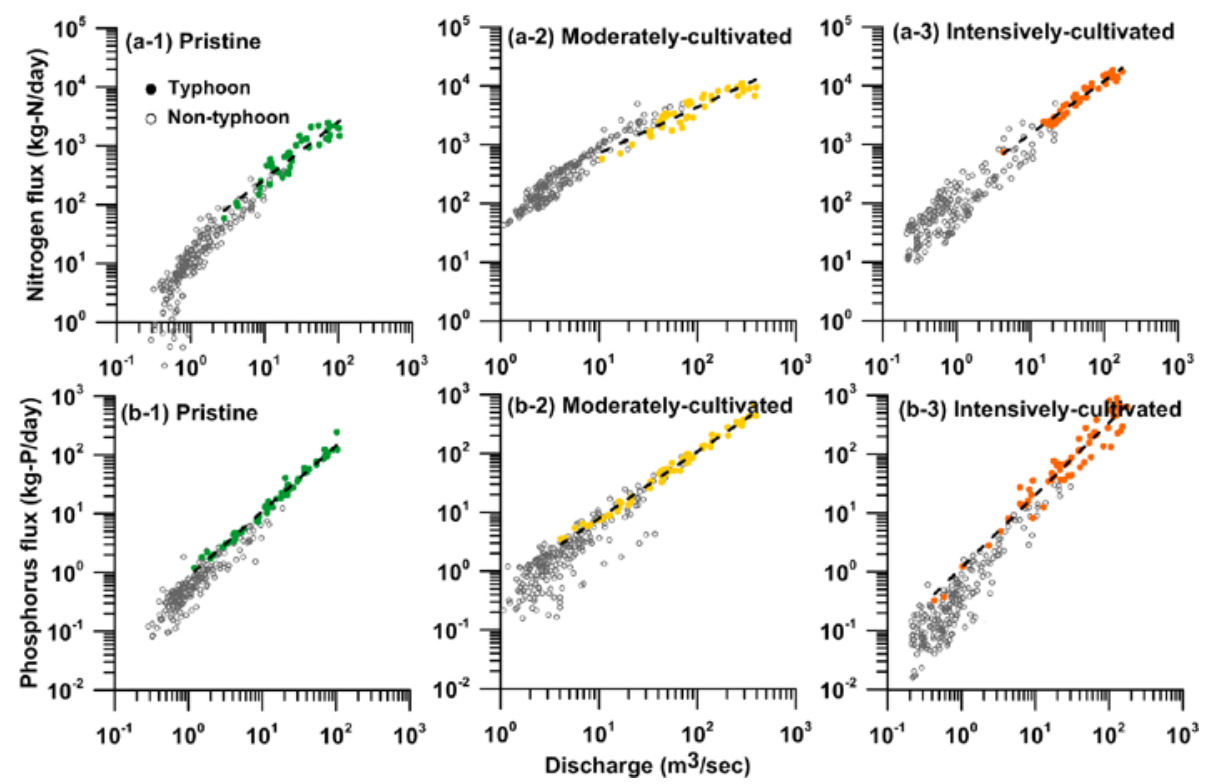

Fig. 8. The log-log graphs of observed (a) nitrogen and (b) phosphorus fluxes against discharge in the pristine (-1), moderately cultivated (-2), and intensively cultivated watersheds (-3). Solid and hollow circles represent typhoon and non-typhoon samples, respectively. The dashed lines stand for the power regression equation of typhoon samples.

$\mathrm{DIN}_{y}$ : DIP $y$ varing from 97 to 410 for the three watersheds (Table 4).

\section{Discussion}

This discussion section will start with the land use alteration on nutrient export (5.1) and then hydrological controls on the nutrient export (5.2). Next, nutrient export will be discussed using a conceptual model (5.3). The significance of the Oceania will be revealed in the end of this section (5.4).

\subsection{Importance of human activity on nutrient export}

Human activities have been demonstrated to be the most significant factors influencing nutrient export (Galloway and Cowling, 2002; Smith et al., 2003; Seitzinger et al., 2010), of which fertilization is highlighted. Our study showed that 
Table 4. Different time frames (annual, typhoon, and non-typhoon period) of the observed runoff, calculated DIN yield (DIN $y$ ), DIP yield $\left(\mathrm{DIP}_{y}\right)$ and $\mathrm{DIN}_{y}$ : DIP $y$ ratios for the three study watersheds. DIN $y$ and $\mathrm{DIP}_{y}$ estimated by the model proposed by Smith et al. (2003) are also in the table.

\begin{tabular}{llccc}
\hline & & Pristine & Moderately cultivated & Intensively cultivated \\
\hline \multirow{2}{*}{ Runoff $(\mathrm{mm})$} & Annual & $3779,3447^{*}$ & 3897,3686 & 2765,2497 \\
& Typhoon & 1253,1655 & 1195,1769 & 1395,1384 \\
& Non-typhoon & 2526,1792 & 2702,1917 & 1370,1113 \\
\hline \multirow{2}{*}{$\operatorname{DIN}_{y}\left(\mathrm{~kg} \mathrm{~N} \mathrm{ha}^{-1} \mathrm{yr}^{-1}\right)$} & Annual & $8.6,7.9$ & 29,22 & 43,30 \\
& Typhoon & $3.8,5.1$ & $6.2,9.1$ & 20,21 \\
& Non-typhoon & $4.8,2.8$ & 23,13 & $22,9.0$ \\
\hline & Annual & $0.35,0.36$ & $0.32,0.37$ & $0.59,0.53$ \\
$\mathrm{DIP}_{y}\left(\mathrm{~kg} \mathrm{Pha}^{-1} \mathrm{yr}^{-1}\right)$ & Typhoon & $0.18,0.24$ & $0.15,0.22$ & $0.49,0.43$ \\
& Non-typhoon & $0.17,0.12$ & $0.17,0.15$ & $0.10,0.10$ \\
\hline \multirow{2}{*}{$\mathrm{DIN}_{y}: \mathrm{DIP}_{y}(\mathrm{molar} \mathrm{ratio})$} & Annual & 108,97 & 410,262 & 323,254 \\
& Nyphoon & 93,94 & 182,181 & 186,225 \\
& Non-typhoon & 126,103 & 613,382 & 1036,369 \\
\hline $\mathrm{DIN}_{y}\left(\mathrm{~kg} \mathrm{Nha}^{-1} \mathrm{yr}^{-1}\right)$ & & & Model estimation (Smith et al., 2003) \\
$\mathrm{DIP}_{y}\left(\mathrm{~kg} \mathrm{Pha}^{-1} \mathrm{yr}^{-1}\right)$ & & $3.7,3.4$ & $3.8,3.6$ & $2.9,2.7$ \\
\hline
\end{tabular}

* Two numbers in one cell stand for values in 2007 and 2008, respectively.

nitrate and phosphate concentrations increase with the increasing proportion of agricultural activity in a watershed. However, the increase in nutrient concentration is so responsive to agricultural activities that even a $2.7 \%$ agricultural land use within a watershed yielded average nitrate concentration increase of $\sim 500 \%$ (Table 2 ) for $\sim 95 \%$ of the year ( $\sim 5 \%$ typhoon excluded), revealing how vulnerable lotic environments are to land use changes in subtropical, mountainous, small rivers. There was $\sim 1000 \%$ increase of nitrate concentration in a watershed with $8.9 \%$ agricultural land.

In Taiwan, the summer typhoon rains force farmers to apply much higher amounts of ammonium sulfate and urea $\left(\sim 3750 \mathrm{~kg} \mathrm{Nha}^{-1} \mathrm{yr}^{-1}\right)$ to support cabbage growth $(\mathrm{N} \mathrm{de-}$ mand $\sim 600-900 \mathrm{~kg} \mathrm{~N} \mathrm{ha}^{-1} \mathrm{yr}^{-1}$ ) and promote early harvest before the typhoon season. The excess fertilization is also due to loss of $\mathrm{N}$ during the wet season. Based on watershed monitoring network in our study area and a sophisticated deconvolution method, Huang et al. (2012b) demonstrated a very high nitrate yield number from active farms, $\sim 3000 \mathrm{~kg} \mathrm{~N} \mathrm{ha}^{-1} \mathrm{yr}^{-1}$, which was the apparent major contributor to enhanced nitrate in stream water. A $1 \%$ increment of active farm land use yields an increase in $\mathrm{DIN}_{y}$ from background $\left(\sim 8.3 \mathrm{~kg} \mathrm{Nha}^{-1} \mathrm{yr}^{-1}\right)$ to $\sim 38 \mathrm{~kg} \mathrm{Nha}^{-1} \mathrm{yr}^{-1}$. The yield from inactive farms, where agricultural activities have been forbidden, was also high at $\sim 770 \mathrm{~kg} \mathrm{Nha}^{-1} \mathrm{yr}^{-1}$ revealing the lingering effect of agricultural activities.

Besides fertilization, widespread anthropogenic $\mathrm{N}$ deposition (ANN) is a major $\mathrm{N}$ source in Oceania (Kao et al., 2004). Atmospheric deposition (long-range transport mainly from China, $\sim 21$ to $\sim 34 \mathrm{~kg} \mathrm{Nha}^{-1} \mathrm{yr}^{-1}$ ) supplements the
$\mathrm{N}$ input, elevating the background yield (King et al., 1994; Chen et al., 1998; Lin et al., 2000; Fang et al., 2008). The $\mathrm{DIN}_{y}$ for Sta. G, $\sim 8.3 \mathrm{~kg} \mathrm{Nha}^{-1} \mathrm{yr}^{-1}$, is higher than most of the rivers draining from land to ocean (Smith et al., 2003) revealing the latent effects of ANN. In the pristine watershed (Sta. G), net increase of DIN inventory is likely occurring in the system. Besides, the DIN leaks out of the forest in growing season (DIN concentration follows the trend of air temperature) showing a syndrome of nitrogen saturation. However, this speculation is difficult to evaluate due to the large $\mathrm{N}$ pool in the soil (see below); meanwhile, the rates of $\mathrm{N}$ mineralization, nitrification (Owen et al., 2010), retention (Fang et al., 2008), and gaseous $\mathrm{N}$ losses (Koba et al., 2012) are influential to nitrogen dynamics and cycling. Whether $\mathrm{N}$ is saturated needs further investigations, potentially the $\mathrm{N}: \mathrm{P}$ in plant foliage (Tessier and Raynal, 2003) and extra N budget terms such as gaseous nitrogen in the watersheds in Taiwan.

Land use effects on phosphate concentration were also found during the typhoon flood; however, there seemed to have a threshold of cultivation level to initiate such an effect; thus only in the intensively cultivated watershed we observed $\sim 2.5 \times$ higher concentrations compared to the other two watersheds (Table 2). At a given TSM in Fig. 5, phosphate concentration is the highest at Sta. Y implying cultivated soil contains more dissolvable phosphate. The DIP $y$ in the intensively cultivated watershed, $\sim 0.56 \mathrm{~kg} \mathrm{Pha}^{-1} \mathrm{yr}^{-1}$, increased $50 \%$ compared to that in the pristine watershed $\left(\sim 0.36 \mathrm{~kg} \mathrm{Pha}^{-1} \mathrm{yr}^{-1}\right.$, Table 4$)$. There is also DIP from the atmospheric deposition $\left(\sim 0.1 \mathrm{~kg} \mathrm{Pha}^{-1} \mathrm{yr}^{-1}\right.$, Mahowald et al., 2008) in this area. Beside the unverified $\mathrm{N}$ saturation, 
more DIP output than input puzzles us. These findings and speculations excite our future studies to unpuzzle the fate of $\mathrm{P}$ and $\mathrm{N}$ in the subtropical watersheds.

The distinct transport behavior between nitrate and phosphate results in high $\operatorname{DIN}_{C}$ : DIP $_{C}$, which is particularly evident in cultivated watersheds. $\operatorname{DIN}_{C}:$ DIP $_{C}$ at the lowest given $Q$ (Fig. 7b-d), i.e., groundwater, reflects the cultivation gradient as well, implying the long-term agricultural activities may have influenced the groundwater. Such high DIN $_{C}:$ DIP $_{C}$ indicates the aquatic ecosystem is mainly limited by DIP (Tseng et al., 2010). Without the DIP export to the stream during typhoon periods, the leakage of DIP from the terrestrial system is likely limited. Overall speaking, the increase in agricultural activity causes a higher $\operatorname{DIN}_{C}$ : DIP $_{C}$ with larger variation.

\subsection{Hydrological control on nutrient exports}

The nitrate and phosphate concentrations showing a positive correlation with discharge imply that the rainfall-runoff process dominates the nutrient export in small mountainous rivers (Figs. 2, 3, and 4). The dominance of discharge on nutrient export is also illustrated by Fig. 8, although in the low-flow condition there seem to be some additional factors scattering the discharge-driven export. The scattering phenomena at low flow, particularly for the phosphate in two cultivate watersheds, may result from local agricultural practice, in-stream biota uptake or some unknown in-stream processes.

Basically, nitrate concentrations increase with increasing water discharge illustrating a typical diffuse source where nitrate is carried along the flow pathways (Salmon et al., 2001; Kao et al., 2004). In general, the hydro-biogeochemical system shows dilution and concentration phenomena due to the alternation of hydrological access for chemicals with large concentration differences between deep and shallow soil components. In our study, the increase of nitrate concentrations with the runoff may resemble the case of enhanced hydrological access to a shallow soil source (Salmon et al., 2001). Dissimilarly, nitrate concentration in surface soil is low in the forest of mountainous Taiwan (Lin et al., 2004). The major reason is that soils on steep slopes in Taiwan are mainly porous, old landsliding material where it is easy for water to infiltrate and be uptaken fast by the shallow-root vegetation.

While rainfall amount is large, exceeding certain thresholds during typhoon or rainstorm periods (e.g., $200 \mathrm{~mm} \mathrm{day}^{-1}$ for nitrate; see Fig. 4a), surface runoff with depleted nitrate dilutes the nitrate concentration in the river. Although the nitrate concentration is diluted during flood periods, the increase in discharge by three orders of magnitude compensates the dilution effect ( $\sim$ one-order magnitude decrease in concentration) and leads to greater transports (Tables 3 and 4). The unceasing DIN export is very likely in Taiwan (Kao et al., 2004) regardless of the cultivation degree.
This may imply that either the nitrogen storage in the watershed is sufficient to afford frequent flooding or that the supplement of nitrogen to the watershed system is fast. The estimation of the total $\mathrm{N}$ pool in soil of the neighboring watershed (Owen et al., 2010) is $6909 \mathrm{~kg} \mathrm{Nha}^{-1}$, approximately $1000 \times$ the export from pristine watersheds, which supports our speculation of sufficient nitrogen storage.

The hydrological control on phosphate is more remarkable than on nitrate. The consistent positive correlation between phosphate concentration and discharge indicates there is always more phosphate input to the stream while discharge increases. Increasing phosphate concentration accompanies the increase in discharge, congruent with the hydrologic controls on the enhancement of phosphate concentration in other watersheds (Sharpley and Menzel, 1987; Correll et al., 1999, Fig. 4b). Increasing TSM triggered by increasing surface runoff is the most possible cause (Fig. 5). The phosphate concentration reached its highest annual value during typhoon events due to greater soil erosion. The attached phosphate is carried into the river with soil particles. During the typhoon periods, the increase of discharge and phosphate concentration by three and two orders of magnitude, respectively (Fig. 8), substantially enhances the phosphorus export (Correll et al., 1999; Green and Finlay, 2010).

Beside the total export, hydrology also modulates the DIN $_{C}:$ DIP $_{C}$ through different hydrological pathways. The imbalanced DIN and DIP productions responding to different hydrological conditions lead to the transition of $\operatorname{DIN}_{C}$ : DIP $_{C}$ from dry to wet seasons (Fig. 7b-d). In the dry season, i.e., low-flow condition, when groundwater dominates the hydrograph, the DIN $_{C}:$ DIP $_{C}$ is categorized as background condition. While approaching high-flow condition, water level is increasing, which induces more flushable nitrate, mainly from soil, to the stream and leads to higher DIN $_{C}$ : DIP . When discharge surges during typhoon or rainstorm periods, surface runoff dominating the hydrograph $(>50 \%$ total discharge; Lee, 2012) enhances phosphate and dilutes nitrate, which reduces the DIN $_{C}$ : DIP $P_{C}$ significantly (Saunder et al., 2006; Green et al., 2007). From the previous section, we have known that $\operatorname{DIN}_{C}: \operatorname{DIP}_{C}$ is agriculture dependent. Concentration of DIN and DIP sources vary with the cultivation gradient, i.e., higher cultivation levels have higher DIN and DIP concentrations.

Although hydrological forcing (i.e., typhoon and rainstorm floods) caused a sharp drop in the $\operatorname{DIN}_{C}$ : DIP $_{C}$ (not so much so in the pristine watershed), the $\operatorname{DIN}_{C}$ : DIP $_{C}$ in the sequential months (September after August and November after October) immediately rebounded (red arrows in Fig. 6), which revealed a quick resilience of the lotic environment from the episodic natural disturbances, i.e., typhoons. There were almost no lingering influences of typhoons, e.g., brash and fallen foliage, since most of them are carried off the watershed by the dominant surface runoff (West et al., 2011). When we went into the detailed chemograph, we saw that DIN $_{C}$ : DIP $_{C}$ returned gradually to the pre-event level while 

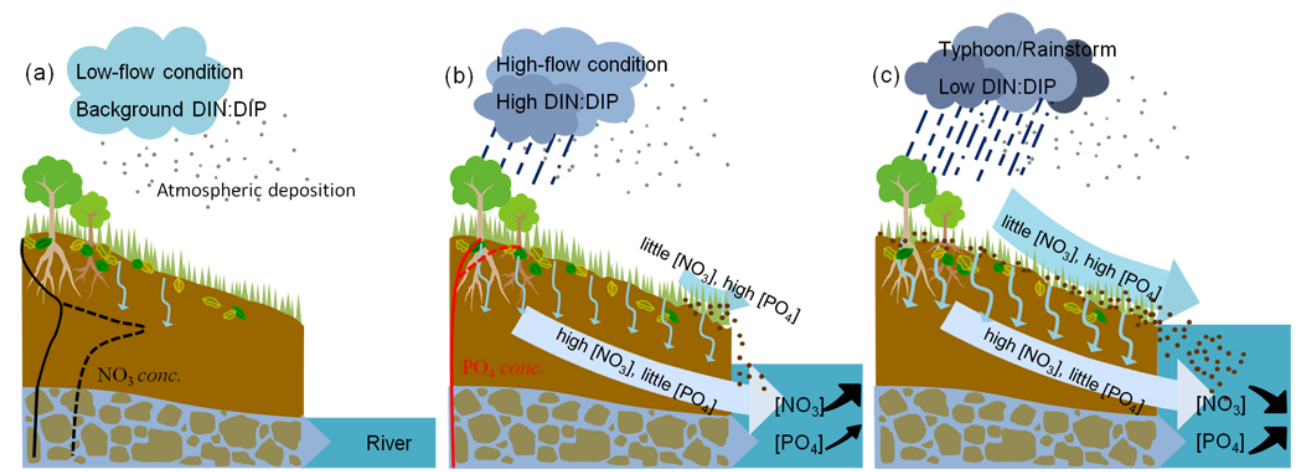

Fig. 9. The schematic diagram of the conceptual model illustrating nutrient export in (a) low-flow condition and dry season; (b) high-flow condition; (c) typhoon and rainstorm flood condition. The arrow size represents the runoff amount. [ ] denotes concentration. The increase or decrease of concentration and its significance was marked. $\mathrm{NO}_{3}$ (black line) and $\mathrm{PO}_{4}$ (red line) concentrations in the soil profile of pristine (solid line) and cultivated (dashed line) land are shown.

the hydrograph receded (not shown). The dramatic change of fluvial nutrient status may be one of the unique characteristics of small mountainous rivers.

\subsection{Differential transport for DIN and DIP}

In this study, a conceptual model is proposed to illustrate the transport of nitrate and phosphate in different hydrological conditions (Fig. 9). During the dry period (from November to April, which is also off-growing season, Fig. 9a) water level is low and dominated by groundwater, which represents the background nitrate and phosphate concentration in a watershed. Foliage from the deciduous forest is fallen on the ground and begins to decompose. On the cultivated land, farmers usually overturn the residuals of the harvested crop into the surface soil in the off-growing season to produce nutrient for the next growing period. In addition, the atmospheric deposition prevails in Taiwan. Small rain events in the dry season leach nutrient, mostly nitrate, into the shallow soil (Fig. 9a) as the $\mathrm{N}$-draining mechanism addressed by Creed et al. (1996). Most of phosphate remains in the surface attached to the soil particles. Since the beginning of the wet season (from May to October excluding typhoon and rainstorm events, Fig. 9b), relatively large rain events increase the water level flushing out the nitrate stored in the soil to the stream. In this condition, most of the additional stream discharge comes from the subsurface that contains more nitrate yet less phosphate; therefore, DIN $_{C}$ : DIP $_{C}$ increases significantly (Fig. 7). Meanwhile, surface soil erosion occurring at the saturated hill foot, where surface runoff is generated, increases phosphate concentration in the river (Huang et al., 2009). During typhoon or rainstorm floods (Fig. 9c), stream discharge, dominated by surface runoff in which nitrate is depleted, decreases nitrate concentration in the river. But the surface runoff containing abundant particle-associated phosphate increases phosphate concentration, resulting in significantly lower DIN ${ }_{C}$ : DIP $_{C}$ (Fig. 7). The transport mech- anism is applicable for different cultivation levels, which only influence the nutrient concentrations of the sources, i.e., surface, subsurface water and groundwater. Various proportions of different flow pathways determine the behaviors of a stream's nutrient concentration (Mulholland and Hill, 1997; Katsuyama et al., 2001; Poor and McDonnell, 2007). Both hydrological control and land use alternation are important to regulate DIN and DIP transport in Oceania rivers.

\subsection{Significance of Oceania streams}

Smith et al. (2003) investigated DIN and DIP loads from 165 sites occupying $35 \%$ of the total land area on Earth. About $60 \%$ of the catchments they used have areas between $10^{3}$ and $10^{5} \mathrm{~km}^{2}\left(10^{1}\right.$ to $10^{7} \mathrm{~km}^{2}$ of full range). The DIN $y$ and DIP $_{y}$ of our three watersheds overwhelm most of these sites. Among 111 large rivers (the minimum watershed area of $8011 \mathrm{~km}^{2}$ ) in the world, which Harrison et al. (2005) analyzed, only 14 of them have higher $\operatorname{DIP}_{y}$ than our pristine watershed, $\sim 0.36 \mathrm{~kg} \mathrm{Pha}^{-1} \mathrm{yr}^{-1}$. Unlike those large rivers having only $\sim 0.33 \mathrm{~m} \mathrm{yr}^{-1}$ in runoff depth, the Oceania rivers have $\sim 2 \mathrm{~m} \mathrm{yr}^{-1}$. It is runoff depth, i.e., hydrological control, that leads to the high DIN and DIP yield of the Oceania rivers. The high fluvial DIP $y$ is mainly attributed to frequent cyclone strikes (Greeen and Finlay, 2010). If the contributions from the typhoons are removed (Table 4), DIP $y$ will be comparable to that of the large rivers. However, even if the contribution of typhoons is removed, DIN $y$ still remains at a high level compared to the world rivers because of the unceasing leakage from terrestrial $\mathrm{N}$ storage. We are likely facing increasing typhoon strikes in terms of frequency and intensity due to climate change (Tu et al., 2009); the alteration of nutrient export and the consequent effects on coastal environment deserve more attention.

Smith et al. (2003) developed a statistic model using $\log$ (population density (people $\mathrm{km}^{-2}$ )) and $\log ($ runoff depth $\left.\left(\mathrm{m} \mathrm{yr}^{-1}\right)\right)$ to estimate $\operatorname{DIN}_{y}$ and $\operatorname{DIP}_{y}$. However, the 
parameterized function only estimates less than $50 \%$ of DIN $_{y}$ in our pristine watershed (Table 4). In their study, only six catchments, catchment size smaller than $10^{2} \mathrm{~km}^{2}$, were used in the analysis and the basin characteristics were poorly resolved. The underestimation is understandable since the function is basically determined by large rivers. The lack of a land use associated factor in the function might have aggravated the underestimation. It is particularly crucial for Oceania, where human population usually concentrates in certain districts. Human population actually consumes agricultural products from other areas, e.g., headwater catchments. Considering the concept of ecological footprint, the population that feeds on those agricultural products should be transferred into the land use alteration effects. However, the controversial overestimation (in the pristine and moderately cultivated watersheds) and underestimation (in the intensively cultivated watershed) on $\operatorname{DIP}_{y}$ of the function created by Smith et al. (2003) merit more detailed investigations on its applicability to $\operatorname{DIP}_{y}$ estimation.

Besides population density and runoff depth in the Smith et al. (2003) equation, air temperature also plays a role, though minor. Temperature negatively correlated to $\mathrm{DIN}_{y}$ in their model suggests the dependence of denitrification on temperature (Knowles, 1981). However, it seems not the case for small mountainous rivers. A positive correlation between nitrate concentration and air temperature was found in our pristine watershed (Fig. 2b). Warmer temperature seems to enhance the rates of organic matter decomposition and nitrification within a watershed. In addition, rapid infiltration in the Oceania river watersheds diminishes denitrification potentials; therefore, even in the cultivated watersheds denitrification signals cannot be detected in stream water (Peng et al., 2012). The temperature dependence disappears due to the significant nitrate sourced from limited cultivated land of the watershed. On the other hand, phosphate does not show any temperature-dependent relations either from Smith compilation or our study.

Seitzinger et al. (2005) developed a complicated model, NEWS (Nutrient Export from Watersheds), to estimate nutrient export from 5761 watersheds. Their $\operatorname{DIN}_{y}$ and DIP $y$ estimations for Oceania, as a function of land use, nutrient inputs, hydrology, and other factors, were $\sim 7.2 \mathrm{~kg} \mathrm{~N} \mathrm{ha}^{-1} \mathrm{yr}^{-1}$ and $\sim 0.28 \mathrm{~kg} \mathrm{Pha}^{-1} \mathrm{yr}^{-1}$, respectively, the highest among eight continents, highlighting the significance of nutrient yields from Oceania. This amount of nitrogen is almost identical to our yield from the pristine watershed (7.9$8.6 \mathrm{~kg} \mathrm{Nha}^{-1} \mathrm{yr}^{-1}$ ). If our case in Taiwan is representative of the background of the entire Oceania, the $\mathrm{N}$ yields from Seitzinger et al. (2005) highly likely underestimate the Oceania export. A similar situation existed in $\mathrm{DIP}_{y}$ estimation, where their model-estimated DIP $y$ is even smaller than from our pristine background $\left(\sim 0.36 \mathrm{~kg} \mathrm{Pha}^{-1} \mathrm{yr}^{-1}\right)$. Once we superimposed the influence of population, such as sewage, the largest anthropogenic source of DIP to the costal zones (Harrison et al., 2005), the DIP $y$ yield from the entire Ocea- nia should be much higher than their model's simulation. It is well known that Oceania characterizes the world's highest sediment yields (Milliman and Syvitski, 1992) and Taiwan rivers feature more extraordinary values (Mulder and Syvitski, 1995; Milliman and Kao, 2005), implying the significance of particulate nitrogen and phosphorus export. However, this entire study focuses on DIN and DIP export, which are more directly accessible by biota and are influential to the aquatic ecosystem.

A N-limited ocean demands nitrogen input. N-loaded fluvial water from Oceania is hence a very important supplement to the ocean. It is particularly important because Oceania is surrounded by an oligotrophic ocean where additional $\mathrm{N}$ input will significantly enhance its productivity and trigger biogeochemical cycles. Our study showed that the ratio of annual DIN $y$ to DIP $y$ ranged from 97-410 (Table 4), higher than the global average (18:1, Smith et al., 2003), featuring evident $\mathrm{N}$ accessibility. Stemming from rapid urbanization, massive loadings of nutrients and organics to rivers have caused dramatic changes of nutrient status in adjacent estuarine and coastal ecosystems (Jickells, 1998; Galloway et al., 2004).Oceania is facing rapid development leading to abundant nutrient-enriched fluvial water $(\sim 12 \%$ annual global discharge) to the ocean, which might further influence global biogeochemical cycles.

\section{Conclusion}

The rainfall-runoff process plays a critical role in releasing DIN and DIP via different mechanisms from subsurface and surface reservoirs, respectively, into streams, modulating the ratio of DIN $_{C}$ to $\mathrm{DIP}_{C}$ that may influence the production and phytoplankton/microbial community structures in the downstream aquatic system. Cultivation gradient interplaying with hydrological conditions results in a wide range of DIN $_{C}:$ DIP $_{C}$ varying from $\sim 20$ to $\sim 8000$. Such high DIN $_{C}:$ DIP $_{C}$ indicates the aquatic ecosystem is mainly limited by DIP. Without heavy rain brought by typhoons or rainstorms to generate surface erosion, the leakage of DIP from the terrestrial system is likely limited. On the other hand, the intensive typhoon rain engenders deeper irrigation to flush out DIN stored in deeper soil, of which plants are not easy to access. Obviously, typhoons are crucial in regulating the absolute and relative amount of DIN and DIP discharges. Much higher increase in DIN relative to DIP caused by cultivation implies that Oceania rivers are sensitive to DIN addition. The rapid flushing and irrigation caused by typhoon rain in summer may push farmers to over-fertilize in order to enhance vegetable production, similarly, the DIN leaks out of the forest in the growing season showing a syndrome of nitrogen saturation. However, in comparison with the atmospheric deposition $\left(\sim 21-34 \mathrm{~kg} \mathrm{Nha}^{-1} \mathrm{yr}^{-1}\right)$ the pristine watershed retains $\sim 70 \%$ of atmospheric DIN input showing a strong uptake capability. Such result points out the next 
task of properly defining the degree of nitrogen saturation for Oceania watersheds. Besides, more DIP output than input deserves our attention as well. Our study also shed light on how to project the future trend of DIN and DIP export from Oceania rivers under the scenario of increasing frequency and intensity of tropical cyclones under global warming conditions.

Acknowledgements. This study is supported by Taiwan National Science Council (98-2116-M-001-005, 99-2116-M-034-001-MY2, 99-2116-M-001-011, 100-2116-M-001-014-MY2, 100-2621-M001-003 -MY3) and Shei-Pa National Park Administration. We also thank Taiwan Power Company and Water Resources Agency for providing hydrological records. We are especially grateful to two reviewers, Wilfred Wollheim and Susan Ziegler. Their constructive suggestions definitely made this scientific article more valuable.

Edited by: B. A. Bergamaschi

\section{References}

Billen, G. and Garnier, J.: River basin nutrient delivery to the coastal sea: Assessing its potential to sustain new production of nonsiliceous algae, Mar. Chem., 106, 148-160, doi:110.1016.j.marchem.2006. 1012.1017, 2007.

Bennett, E. M., Carpenter, S. R., and Caraco, N. F.: Human impact on erodable phosphorous and eutrophication: A global perspective, Bioscience, 51, 227-234, 2001.

Bouwman, A. F., Van Drecht, G., Knoop, J. M., Beusen, A. H. W., and Meinardi, C. R.: Exploring changes in river nitrogen export to the world's oceans, Global Biogeochem. Cy., 19, GB1002, doi:10.1029/2004GB002314, 2005.

Caraco, N. F. and Cole, J. J.: Human impact on nitrate export: an analysis using major world rivers, Ambio, 28, 167-170, 1999.

Carey, A. E., Nezat, C. A., Lyons, W. B., Kao, S. J., Hicks, D. M., and Owen, J. S.: Trace metal fluxes to the ocean: the importance of high-standing oceanic islands, Geophys. Res. Lett., 29, 2099, doi:10.1029/2002GL015690, 2002.

Chen, Z. S., Liu, J. C., and Cheng, C. Y.: Acid deposition effects on the dynamic of heavy metals in soils and their biological accumulation in the crops and vegetables in Taiwan, in: Acid Deposition and Ecosystem Sensitivity in East Asia, edited by: Bashkin V. and Park S. U., Nova Science Publishers, Hauppauge, NY, 188225, 1998.

Coats, R., Liu, F., and Goldman, C. R.: A monte carlo test of load calculation methods, Lake Tahoe Basin, California-Nevada, J. Am. Water Resour. As., 38, 719-730, 2002.

Conley, D. J., Paer, H. W., Howarth, R. W., Boesch, D. F., Seitzinger, S. P., Havens, K. E., Lancelot, C., and Likens, G. E.: Controlling eutrophication: nitrogen and phosphorus, Science, 323, 1014-1015, 2009.

Correll, D. L., Jordan, T. E., and Weller, D. E.: Transport of nitrogen and phosphorus from Rhode River watersheds during storm events. Water Resour. Res., 35, 2513-2521, 1999.

Creed, I. F., Band, L. E., Foster, N. W., Morrison, I. K., Nicolson, J. A., Semkin, R. S., and Jeffries, D. S.: Regulation of nitrate-N release from temperate forests: a test of the $\mathrm{N}$ flushing hypothesis, Water Resour. Res., 32, 3337-3354, 1996.
Diaz, R. J. and Rosenberg, R.: Spreading dead zones and consequences for marine ecosystems, Science, 321, 926-929, doi:10.1126/science.1156401, 2008.

Dolan, D. M., Yui, A. K., and Geist, R. D.: Evaluation of river load estimation methods for total phosphorus, J. Great Lakes Res., 7, 207-214, 1981.

Duan, S. W., Xu, F., and Wang, L. J.: Long-term changes in nutrient concentrations of the Changjiang River and principal tributaries, Biogeochemistry, 85, 215-234, 2007.

Elser, J. J., Andersen, T., Baron, J. S., Bergström, A. K., Jansson, M., Kyle, M., Nydick, K. R., Steger, L., and Hessen, D. O.: Shifts in Lake N : P stoichiometry and nutrient limitation driven by atmospheric nitrogen deposition, Science, 326, 835-837, 2009.

Fang, Y. T., Gundersen, P., Mo, J. M., and Zhu, W. X.: Input and output of dissolved organic and inorganic nitrogen in subtropical forests of South China under high air pollution, Biogeosciences, 5, 339-352, doi:10.5194/bg-5-339-2008, 2008.

Galloway, J. N. and Cowling, E. B.: Reactive nitrogen and the world: 200 years of change, Ambio, 31, 64-71, 2002.

Galloway, J. N., Dentener, F. J., Capone, D. G., Boyer, E. W., Howarth, R. W., Seitzinger, S. P., Asner, G. P., Cleveland, C. C., Green, P. A., Holland, E. A., Karl, D. M., Michaels, A. F., Porter, J. H., Townsend, A. R., and Vorosmarty, C. J.: Nitrogen cycles: past, present, and future, Biogeochemistry, 70, 153-226, 2004.

Green, M. B. and Finlay, J. C.: Patterns of hydrologic control over stream water total nitrogen to total phosphorus ratios, Biogeochemistry, 99, 15-30, doi:10.1007/s10533-009-9394-9, 2010.

Green, M. B., Nieber, J. L., Johnson, G., Magner, J., and Schaefer, B.: Flow path influences on an $\mathrm{N}$ : $\mathrm{P}$ ratio in two headwater streams: a paired watershed study, J. Geophys. Res., 112, G03015, doi:10.1029/2007JG000403, 2007.

Harison, J. A., Seitzinger, S. P., Bouwman, A. F., Caraco, N. F., Beusen, A. H. W., and Vorosmarty, C. J.: Dissolved inorganic phosphorus export to the coastal zone: Results from a spatially explicit, global model, Global Biogeochem. Cy., 19, GB4S03, doi:10.1029/2004GB002357, 2005.

Howart, R. W., Billen, G., Swaney, D., Townsend, A., Jaworski, N., Lajtha, K., Downing, J. A., Elmgren, R., Caraco, N., Jordan, T., Berendse, F., Freney, J., Kudeyarov, V., Murdoch, P., and Liang, Z. Z.: Regional nitrogen budgets and riverine $\mathrm{N}$ and $\mathrm{P}$ fluxes for the drainages to the North Atlantic Ocean: Natural and human influences, Biogeochemistry, 35, 75-139, 1996.

Huang, J.-C., Lee, T.-Y., and Kao, S.-J.: Simulating typhooninduced storm hydrographs in subtropical mountainous watershed: an integrated 3-layer TOPMODEL, Hydrol. Earth Syst. Sci., 13, 27-40, doi:10.5194/hess-13-27-2009, 2009.

Huang, J. C., Lin, C. C., Chan, S. C., Lee, T. Y., Hsu, S. C., Lee, C. T., and Lin, J. C.: Stream discharge characteristics through urbanization gradient in Danshui River, Taiwan: perspectives from observation and simulation, Environ. Monit. Assess., 184, 56895703, 2012a.

Huang, J.-C., Lee, T.-Y., Kao, S.-J., Hsu, S.-C., Lin, H.-J., and Peng, T.-R.: Land use effect and hydrological control on nitrate yield in subtropical mountainous watersheds, Hydrol. Earth Syst. Sci., 16, 699-714, doi:10.5194/hess-16-699-2012, 2012 b.

Jickells, T. D.: Nutrient biogeochemistry of the coastal zone, Science, 281, 217-222, 1998.

Justic, D., Rabalais, N. N., Turner, R. E., and Dortch, Q.: Changes in nutrient structure of river-dominated coastal waters: stoichiomet- 
ric nutrient balance and its consequences, Estuar. Coast. Shelf S., 40, 339-356, 1995.

Kao, S. J. and Liu, K. K: Stable carbon and nitrogen isotope systematics in a human-disturbed watershed (Lanyang-Hsi) in Taiwan and the export of biogenic particulate matter, Global Biogeochem. Cy., 14, 189-198, 2000.

Kao, S. J. and Liu, K. K.: Estimating the suspended sediment load by using the historical hydrometric record from the Lanyang-Hsi watershed, Terr. Atmos. Ocean. Sci., 12, 401-414, 2001.

Kao, S. J. and Milliman, J. D.: Water and sediment discharge from small mountainous rivers, Taiwan: The roles of lithology, episodic events, and human activities, J. Geol., 116, 431-448, 2008

Kao, S. J., Shiah, F. K., and Owen, J. S.: Export of dissolved inorganic nitrogen in a partially cultivated subtropical mountainous watershed in Taiwan, Water Air Soil Poll, 156, 211-228, 2004.

Kao, S. J., Lee, T. Y., and Milliman, J. D.: Calculating highly fluctuated suspended sediment fluxes from mountainous rivers in Taiwan, Terr. Atmos. Ocean. Sci., 16, 653-675, 2005.

Kao, S. J., Shiah, F. K., Wang, C. H., and Liu, K. K.: Efficient trapping of organic carbon in sediments on the continental margin with high fluvial sediment input off southwestern Taiwan, Cont. Shelf Res., 26, 2520-2537, 2006.

Katsuyama M., Ohte, N., and Kobashi, S.: A three-component end-member analysis of streamwater hydrochemistry in a small Japanese forested headwater catchment, Hydrol. Process., 15, 249-260, 2001.

King, H. B., Hsia, Y. J., Liou, C. B., Lin, T. C., Wang, L. J., and Hwong, J. L.: Chemistry of precipitation, throughfall, stem flow and streamwater of six forest sites in Taiwan, in: Biodiversity and Terrestrial Ecosystem, edited by: Peng, C. I. and Chou, C. H., Institute of Botany, Academia Sinica, Taiwan, 355-362, 1994.

Knowles, R.: Denitrification. Terrestrial Nitrogen Cycles, in: Ecological Bulletins no. 33, Clark, F. E. and Rosswall, T., Swedish Natural Science Research Council, Stockholm, 315-329, 1981.

Koba, K., Fang, Y., Mo, J., Zhang, W., Liu, X., Liu, L., Zhang, T., Takebayashi, Y., Toyoda, S., Yoshida, N., Suzuki, K., Yoh, M., and Senoo, K.: The ${ }^{15} \mathrm{~N}$ natural abundance of the $\mathrm{N}$ lost from an N-saturated subtropical forest in southern China. J. Geophys. Res., 117, G02015, doi:10.1029/2010JG001615, 2012.

Lee, T. Y.: Study on Integration of Monitoring and Modeling for Analyzing the Effects of Land Use Changes on Water Quality and Stream Temperature in Chichiawan Creek, Ph.D. thesis, Graduate Institute of Bioenvironmental Systems Engineering, National Taiwan University, Taiwan, 2012.

Lee, T. Y., Huang, J. C., Carey, A. E., Hsu, S. C., Selvaraj, K., and Kao, S. J.: Uncertainty in acquiring elemental fluxes from subtropical mountainous rivers, Hydrol. Earth Syst. Sci. Discuss., 6, 7349-7383, doi:10.5194/hessd-6-7349-2009, 2009.

Legates, D. R.: Global and terrestrial precipitation- A comparativeassessment of existing climatologies, Int. J. Climatol., 15, 237258, 1995.

Leithold, E. L., Blair, N. E., and Perkey, D. W.: Geomorphic controls on the age of particulate organic carbon from small mountainous and upland rivers. Global Biogeochem. Cy., 20, GB3022, doi:10.1029/2005GB002677, 2006.

Lin, T. C., Hamburg, S. P., King, H. B., and Hsia, Y. J.: Throughfall patterns in a subtropical rain forest of northeastern Taiwan, J. Environ. Qual., 29, 1186-1193, 2000.
Lin, Y. F., Lin, C. Y., Chou, W. C., Lin, W. T., Tsai, J. S., and Wu, C. F.: Modelling of riparian vegetated buffer strip width and placement: A case study in Shei Pa National Park, Taiwan, Ecol. Eng., 23, 327-339, 2004.

Lu, X.X., Li, S., He, M., Zhou, Y., Bei, R., Li, L., and Ziegler, A. D.: Seasonal changes of nutrient fluxes in the upper Changjiang basin: An example of the Longchuangjiang River, China, J. Hydrol., 405, 344-351, 2011.

Lyons, W. B., Nezat, C. A., Carey, A. E., and Hicks, D. M.: Organic carbon fluxes to the ocean from highstanding islands, Geology, 30, 443-446, 2002.

Mahowald, N., Benitez-Nelson, C. R., Bergametti, G., Bond, T. C., Chen, Y., Cohen, D. D., Herut, B., Kubilay, N., Losno, R., Luo, C., Maechaut, W., McGee, K. A., Okin, G. S., Siefert, R. L., and Tsukuda, S.: Global distribution of atmospheric phosphorus sources, concentrations and deposition rates and antrophogenic impacts, Global Biogeochem. Cy., 22, GB4026, doi:10.1029/2008GB003240, 2008.

Meybeck, M.: Carbon, nitrogen, and phosphorus transport by world rivers, Am. J. Sci., 282, 401-450, 1982.

Milliman, J. D.: Sediment discharge to the ocean from small mountainous rivers: the New Guinea example, Geo-Mar. Lett., 15, 127-133, 1995.

Milliman, J. D. and Kao, S. J.: Hyperpycnal discharge of fluvial sediment to the ocean: impact of Super-typhoon Herb (1996) on Taiwanese Rivers, J. Geol., 113, 503-516, doi:10.1086/431906, 2005.

Milliman, J. D. and Syvitski, J. P. M.: Geomorphic/tectonic control of sediment discharge to the ocean: the importance of small mountainous rivers, J. Geol., 100, 525-544, 1992.

Milliman, J. D., Farnsworth, K. L., and Albertin, C. S.: Flux and fate of fluvial sediments leaving large islands in the East Indies, J. Sea. Res., 41, 97-107, 1999.

Milliman, J. D., Lin, S. W., Kao, S. J., Liu, J. P., Liu, C. S., Chiu, J. K., and Lin, Y. C.: Short-term changes in seafloor character due to flood-derived hyperpycnal discharge: Typhoon Mindulle, Taiwan, July 2004, Geology, 35, 779-782, doi:10.1130/G23760A.1, 2007.

Mulder, T. and Syvitski, J. P. M.: Turbidity currents generated at river mouths during exceptional discharges to the world oceans, J. Geol., 103, 285-299, 1995.

Mulholland, P. J. and Hill, W. R.: Seasonal patterns in streamwater nutrient and dissolved organic carbon concentrations: Separating catchment flow path and in-stream effects, Water Resour. Res., 33, 1297-1306, 1997.

Nittrouer, C. A., Brunskill, G. J., and Figueiredo, A. G.: Importance of tropical coastal environments, Geo-Mar. Lett., 15, 121-126, 1995.

Owen, J. S., King, H. B., Wang, M. K., and Sun, H. L.: Net nitrogen mineralization and nitrification rates in forest soil in northeastern Taiwan, J. Soil Sci. Plant Nut., 56, 177-185, 2010.

Parsons, T. R., Maita, Y., and Lalli, C. M.: A manual of chemical and biological methods for seawater analysis, Pergamon Press, New York, NY, 1984.

Peng, T. R., Lin, H. J., Wang, C. H., Liu, T. S., and Kao, S. J.: Pollution and variation of stream nitrate in a protected high-mountain watershed of Central Taiwan: evidence from nitrate concentration and nitrogen and oxygen isotope compositions, Environ. Monit. Assess., 184, 4985-4998, doi:10.1007/s10661-011-2314- 
$1,2012$.

Poor, C. J. and McDonnell, J. J.: The effects of land use on stream nitrate dynamics, J. Hydrol., 332, 54-68, 2007.

Rabalais, N. N., Wiseman, W. J., Turner, R. E., SenGupta, B. K., and Dortch, Q.: Nutrient changes in the Mississippi River and system responses on the adjacent continental shelf, Estuaries, 19, 386-407, 1996.

Salmon, C. D., Walter, M. T., Hedin, L. O., and Brown, M. G.: Hydrolgoical controls on chemical export from an undisturbed oldgrowth Chilean forest, J. Hydrol., 253, 69-80, 2001.

Saunder, T. J., McClain, M. E., and Llerena, C. A.: The biogeochemistry of dissolved nitrogen, phosphorus, and organic carbon along terrestrial-aquatic flowpaths of a montane headwater catchment in the Peruvian Amazon, Hydrol. Process., 20, 2549-2562, doi:10.1002/hyp.6215, 2006.

Seitzinger, S. P., Harrison, J. A., Dumont, E., Beusen, A. H. W., and Bouwman, A. F.: Sources and delivery of carbon, nitrogen, and phosphorus to the coastal zone: An overview of Global Nutrient Export from Watersheds (NEWS) models and their application, Global Biogeochem. Cy., GB4S01, doi:10.1029/2005GB002606, 2005.

Seitzinger, S. P., Mayorga, E., Bouwman, A. F., Kroeze, C., Beusen, A. H. W., Billen, G., Van Drecht, G., Dumont, E., Fekete, B. M., Garnier, J., and Harrison, J. A.: Global river nutrient export: A scenario analysis of past and future trends, Global Biogeochem. Cy., 24, GB0A08, doi:10.1029/2009GB003587, 2010.

Sharpley, A. N. and Menzel, R. G.: The impact of soil and fertilizer phosphorus on the environment, Adv. Agron., 41, 297-324, 1987.

Smith, S. V., Swaney, D. P., Talaue-McManus, L., Bartley, J. D., Sandhei, P. T., McLaughlin, C. J., Dupra, V. C., Crossland, C. J., Buddemeier, R. W., Maxwell, B. A., and Wulff, F.: Humans, hydrology, and the distribution of inorganic nutrient loading to the ocean, Bioscience, 53, 235-245, 2003.
Tessier, J. T. and Raynal, D. J.: Use of nitrogen to phosphorus ratios in plant tissue as an indicator of nutrient limitation and nitrogen saturation, J. Appl. Ecol., 40, 523-534, 2003.

Tseng, Y. F., Hsu, T. C., Chen, Y. L., Kao, S. J., Wu, J. T., Lu, J. C., Lai, C. C., Kuo, H. Y., Lin, C. H., Yamamoto, Y., Xiao, T., and Shiah, F. K.: Typhoon effects on DOC dynamics in a phosphatelimited reservoir, Aquat. Microb. Ecol., 60, 247-260, 2010.

Tu, J. Y., Chou, C., and Chu, P. S.: The Abrupt Shift of Typhoon Activity in the Vicinity of Taiwan and Its Association with Western North Pacific-East Asian Climate Change, J. Climate, 22, 36173628, doi:10.1175/2009JCLI2411.1, 2009.

Tung, C. P., Lee, T. Y., and Yang, Y. C.: Modelling climate-change impacts on stream temperature of Formosan Landlocked Salmon habitat, Hydrol. Process., 20, 1629-1649, 2006.

Turner, R. E., Rabalais, N. N., Justic, D., and Dortch, Q.: Global patterns of dissolved N, P and Si in large rivers, Biogeochemistry, 64, 297-317, 2003.

United States Geological Survey: Mineral Commodity Summaries 2008, US Geol. Survey, US Dept of the Inter., ISBN:9781411320765, available at: http://minerals.usgs.gov/ minerals/pubs/mcs/2008/mcs2008.pdf, 2008.

West, A. J., Lin, C. W., Lin, T. C., Hilton, R. G., Liu, S. H., Chang, C. T., Lin, K. C., Galy, A., Sparkers, R. B., and Hovius, N.: Mobilization and transport of coarse woody debris to the oceans triggered by an extreme tropical storm, Limnol. Oceanogr., 56, 77-85, 2011.

Yu, S. F., Lin, Y. F., Kuan, W. H., and Lin, H. J.: A study of water quality of Wulin area in Sheipa National Park, Journal of National Park, 15, 45-60, 2005. 